\title{
Sustainable forest biomass: a review of current residue harvesting guidelines
}

\author{
Brian D. Titus ${ }^{1,2^{*}}$, Kevin Brown ${ }^{1,3}$, Heljä-Sisko Helmisaari ${ }^{4}$, Elena Vanguelova ${ }^{5}$, Inge Stupak ${ }^{6}$, Alexander Evans ${ }^{7}$, \\ Nicholas Clarke ${ }^{8}$, Claudia Guidi ${ }^{9}$, Viktor J. Bruckman ${ }^{10}$, Iveta Varnagiryte-Kabasinskiene ${ }^{11}$, Kęstutis Armolaitis ${ }^{11}$, \\ Wim de Vries ${ }^{12}$, Keizo Hirai ${ }^{13}$, Lilli Kaarakka ${ }^{14}$, Karen Hogg ${ }^{1}$ and Pam Reece ${ }^{1,15}$
}

\begin{abstract}
Forest biomass harvesting guidelines help ensure the ecological sustainability of forest residue harvesting for bioenergy and bioproducts, and hence contribute to social license for a growing bioeconomy. Guidelines, typically voluntary, provide a means to achieve outcomes often required by legislation, and must address needs related to local or regional context, jurisdictional compatibility with regulations, issues of temporal and spatial scale, and incorporation of appropriate scientific information. Given this complexity, comprehensive reviews of existing guidelines can aid in development of new guidelines or revision of existing ones. We reviewed 32 guidelines covering 43 jurisdictions in the USA, Canada, Europe and East Asia to expand upon information evaluated and recommendations provided in previous guideline reviews, and compiled a searchable spreadsheet of direct quotations from documents as a foundation for our review. Guidelines were considered in the context of sustainable forest management (SFM), focusing on guideline scope and objectives, environmental sustainability concerns (soils, site productivity, biodiversity, water and carbon) and social concerns (visual aesthetics, recreation, and preservation of cultural, historical and archaeological sites). We discuss the role of guidelines within the context of other governance mechanisms such as SFM policies, trade regulations and non-state market-driven (NSMD) standards, including certification systems. The review provides a comprehensive resource for those developing guidelines, or defining sustainability standards for market access or compliance with public regulations, and/or concerned about the sustainability of forest biomass harvesting. We recommend that those developing or updating guidelines consider (i) the importance of well-defined and understood terminology, consistent where possible with guidelines in other jurisdictions or regions; (ii) guidance based on locally relevant research, and periodically updated to incorporate current knowledge and operational experience; (iii) use of indicators of sensitive soils, sites, and stands which are relevant to ecological processes and can be applied operationally; and (iv) incorporation of climate impacts, long-term soil carbon storage, and general carbon balance considerations when defining sustainable forest biomass availability. Successful implementation of guidelines depends both on the relevance of the information and on the process used to develop and communicate it; hence, appropriate stakeholders should be involved early in guideline development.
\end{abstract}

Keywords: Forest biomass, Harvesting residue removal, Guidelines, Governance, Sustainability, Biodiversity, Soil, Water, Carbon, Review

*Correspondence: Brian.Titus@Canada.ca

${ }^{1}$ Canadian Forest Service, Pacific Forestry Centre, Natural Resources Canada, 506 West Burnside Rd, Victoria, BC V8Z 1M5, Canada

Full list of author information is available at the end of the article

\section{Introduction}

Growth in the renewable energy sector has been spurred by the need to reduce greenhouse gas (GHG) emissions, and by technological advances and decreased production costs [1]. Fourteen percent of energy consumed original author(s) and the source, provide a link to the Creative Commons licence, and indicate if changes were made. The images or other third party material in this article are included in the article's Creative Commons licence, unless indicated otherwise in a credit line to the material. If material is not included in the article's Creative Commons licence and your intended use is not permitted by statutory regulation or exceeds the permitted use, you will need to obtain permission directly from the copyright holder. To view a copy of this licence, visit http://creativecommons.org/licenses/by/4.0/. The Creative Commons Public Domain Dedication waiver (http://creativeco mmons.org/publicdomain/zero/1.0/) applies to the data made available in this article, unless otherwise stated in a credit line to the data. 
globally in 2017 was from biomass, making it by far the largest form of renewable energy (i.e. $96 \%$ of heat and $9 \%$ of electrical production [2]). More than $85 \%$ of this biomass came from forests or the forest industry [2], which is similar to the proportion in 2014 (87\%) when the forest biomass supply (derived from [3]) consisted of fuelwood (77\%), charcoal $(8 \%)$, recovered wood $(7 \%)$, conventional (or traditional) forest product manufacturing residues $(7 \%)$ and forest harvest residues (1\%). Although the global proportion of the latter two is small, in 2016 approximately $25 \%$ of Swedish energy was produced from a wide range of forestry feedstocks [4], and solid wood fuels accounted for 15\% of Finnish energy consumption [5]. Growth in bioenergy use is projected to increase sharply over the next several decades [6] to meet requirements for greater proportions of energy from renewable sources (e.g. [7]), which will undoubtedly increase demand for bioenergy feedstocks from forestry.

There are two main classes of forestry-derived biomass: primary feedstocks removed from forests, and secondary feedstocks as by-products from forest manufacturing [8]. Primary feedstocks from otherwise non-merchantable tree components include (i) residues left from harvesting merchantable trees (typically tops, branches and foliage, but sometimes stumps and roots); (ii) sub-merchantable stems or whole trees (i.e. all above-ground tree components) left after commercial harvesting, or whole trees harvested in pre-commercial thinning or at final felling; and (iii) stems salvaged after disturbances such as fire, insect infestations and diseases. Forest harvest residue is sometimes known regionally as "slash" or "brash" and is included in "energy wood" in jurisdictions that use this latter term. From an ecological perspective, whole-tree harvesting is the equivalent of stem-only harvesting plus harvest residue removal and is sometimes known as "fulltree harvesting" in parts of North America and Europe (e.g. Austria). Secondary feedstocks include bark, chips, sawdust, black liquor and tall oil from sawmills and pulp mills [9], amongst other by-products from processing wood.

Using forest biomass from the forestry sector to produce renewable energy has a number of advantages: energy can be produced from small to large scales, and can supply electricity to the grid at a steadier rate than intermittent solar or wind power because it is not weather-dependent [10-13]. Furthermore, forest biomass can be co-managed with conventional timber [14] to create bioenergy feedstock from material that might otherwise be burned on-site or left to decompose [10], or removed to reduce fuel loading in fire-prone areas $[10,11,15,16]$ or facilitate replanting of harvested sites. Where there are markets, forest harvest residues can increase the economic value of products from managed forests, and may also stabilize carbon (C) stocks in fireprone forests [17] and thus prevent conversion of some forest land to other land uses because of the value of these C stocks [18].

Manufacturing residues account for a large proportion of forest bioenergy production compared to harvest residues (79\% cf. 9\% in Sweden in 2015 [9]) but there is scope for increased use of the latter. It is estimated that 2015 Swedish forest bioenergy production of 36 PJ from harvest residues plus $1 \mathrm{PJ}$ from stumps could be increased and, when combined with roundwood and small-diameter trees, would almost triple energy production to $98 \mathrm{PJ}$ compared to $144 \mathrm{PJ}$ from secondary forest manufacturing residues [19]. Globally, there is less discrepancy between these two main sources of biomass: estimated annual potential of harvest residues is 371 million dry tonnes compared to 406 million dry tonnes for manufacturing residues [3].

Given the renewable energy targets that countries have set for themselves, the continuing growth in bioenergy production, and the potential for increasing removal of forest harvest residues (hereafter referred to as "forest biomass") for use as bioenergy feedstock, it is paramount that these removals be environmentally sustainable. Applying sustainable forest management (SFM) principles, criteria and indicators (e.g. [20]) helps ensure that forest biomass harvesting is ecologically sustainable (e.g. [21, 22]) and socially acceptable. However, practices considered ecologically sustainable for conventional stem-only harvesting may not necessarily be sustainable when residue is also harvested [23-27]. Furthermore, practices considered acceptable in conventional forestry are not always considered acceptable for forest biomass harvesting; in Minnesota, for example, forest managers are advised to remove stumps to limit spread of root diseases [28] but not to remove stumps for bioenergy; and in New Brunswick, guidelines restrict the removal of harvest residue (tops and branches) for bioenergy but not pulpwood fibre generated from whole-tree chipping [29]. Hence, governments and non-governmental organizations have developed a range of related governance tools (such as policies, regulations, certification schemes and guidelines) to help ensure that forest biomass harvesting is environmentally sustainable [30-32].

Within this suite of tools, forest biomass harvesting guidelines (hereafter referred to as "biomass harvesting guidelines") are sets of recommended (but not necessarily mandatory) SFM practices, and provide clarification and interpretation of these practices that can be flexibly applied to achieve desired or legislated outcomes (e.g. $[33,34])$. Use of governance terms can vary between jurisdictions, and biomass harvesting guidelines are sometimes called "best management practices" (or 
BMPs); however, in the USA and British Columbia this term typically refers to practices applied to protect water quality. Like guidelines, BMPs are also typically voluntary and often include adaptive management principles [35]; however, they may require a higher standard of practice than "acceptable management practices" (AMPs; e.g. [36]) contained in guidelines, and can be mandatory [37, 38]. Voluntary and mandatory requirements are sometimes combined; for example, voluntary forestry BMPs in North Carolina support mandatory forest practice guidelines for protecting water quality [39]. Terminology also differs somewhat in the United Kingdom (UK), where there are two levels of compliance for forest management: "guidance" gives advice for "good forestry practice requirements", and "guidelines" outline more stringent "legal requirements" [34].

Biomass harvesting guidelines were first produced in Denmark in 1985, followed by Sweden in 1986, in response to concerns about the potential environmental impacts of intensified forest biomass harvesting [30, $40,41]$. Since then, many jurisdictions (i.e. countries, or states or provinces within a country and with legislative power) or regions of countries have developed or considered developing their own guidelines. The demand for forest biomass, and hence for biomass harvesting guidelines, will likely grow as GHG emission reduction policies, improvements in biomass conversion technology and increasingly efficient harvesting practices reduce forest bioenergy costs and increase feedstock value [42-45]. Current forest operations can leave as little as $11 \%$ of harvesting residues on some sites [46] and guidelines can help ensure sustainability once this feedstock has enough economic value to justify removal across a wider range of sites.

Biomass harvesting guidelines must address complex needs related to local or regional context, jurisdictional compatibility with regulations, issues of temporal and spatial scale, and incorporation of appropriate science (e.g. [32, 47, 48]). Proxies for these sometimes-conflicting needs are then needed that are operationally applicable (e.g. amount of residue left on-site). Given this complexity, comprehensive reviews of existing biomass harvesting guidelines can aid development of new guidelines or revision of existing ones. At least 16 guideline reviews have been published since 2007 (Additional file 1: Table ST-1), but many are restricted to a few topics, jurisdictions or regions, and are based on guidelines in English; furthermore, specific details from original guidelines are often omitted from reviews. An updated and comprehensive review of guidelines that includes more indepth detail and documents not available in English is warranted. Our objective was to review guidelines for removing forest harvest residues from sites and provide a comprehensive resource based on collation of verbatim details for guideline developers (government, industry, forestry organizations), policy-makers and third-parties who develop sustainability standards for market access, and for organizations and practitioners concerned about the sustainability of forest biomass harvesting.

In this review we (i) provide details contained in original documents by compiling direct quotations from specific guidelines in a supplementary Excel worksheet, organized in a manner consistent with the environmental criteria of SFM; (ii) summarize details and discuss key topics such as guideline scope and objectives, and how these address key environmental sustainability concerns (soils, site productivity, biodiversity, water and carbon) and social concerns (visual aesthetics, recreation, and preservation of cultural, historical and archaeological sites); (iii) consider the role of guidelines within the context of other governance mechanisms (such as SFM policies, trade regulations, non-state market-driven (NMSD) standards, including certification systems); and (iv) recommend what to consider when developing or updating guidelines.

\section{Methods}

Biomass harvesting guidelines were identified through internet searches and discussion with specialists. The search began with countries belonging to the Organisation for Economic Cooperation and Development (OECD), but was then expanded world-wide. Primary documents were sought that specifically addressed removal of forest harvest residues from sites, including (i) tops, branches and foliage from merchantable stems (either in second operation to collect residue after stems removed from site, or as whole trees at final felling); (ii) sub-merchantable stems; (iii) whole-tree thinning, and (iv) stumps and roots; but not including merchantable stems. Specific guidelines for stump harvesting and wood ash fertilization were beyond the scope of our objective and therefore not reviewed, but information on these two topics was included when it was part of biomass harvesting guidelines [see [49-51] for reviews of guidelines for ash application ("ashing") and stump removal ("stumping")]. Biomass harvesting guidance was found in stand-alone documents or integrated within general forest management guidelines or regulations, but identified as biomass harvesting guidance. We included general forest management documents only when explicitly linked to biomass harvesting guidelines (e.g. some American states). We also included five jurisdictions (Austria, Italy, Lithuania, Norway, Japan) that did not have specific guidelines, but were represented at an OECDsponsored workshop that gave impetus to the review. For these, relevant SFM or certification guidelines or 
similar documents relevant to forest biomass harvesting were used. Some guidelines were revised once data had already been entered in our worksheet; these earlier data are retained in Additional file 1: Table ST-1, but were not considered further.

For each guideline, we recorded (i) meta-data (e.g. reference, language); (ii) development process (e.g. extent of stakeholder participation, use of scientific knowledge); (iii) application (e.g. private vs. public forest land, voluntary vs. mandatory) and (iv) context (e.g. relationship to planning, SFM compliance and effectiveness monitoring, adaptive management). We then searched documents for (v) indicators of site or stand conditions for which guidelines are particularly important; (vi) guidance or regulations governing actions (e.g. "do" or "do not"), and (vii) the environmental and social values that the guidelines were designed to protect.

We copied direct quotations from English-language guidelines, or from unofficial translations provided by members of the project team if guidelines were not in English, into an Excel worksheet (Additional file 1: Table ST-1). Information was then categorized by features that were common to the majority of guidelines using a fourtier hierarchy of (i) eight general categories (meta-data, forest management activity, forest biomass component of interest, soil, biodiversity, water, carbon, social values) with (ii) 46 mid-level categories (Table 1), and then (iii) 136 detailed categories with a further (iv) 40 sub-details for some of the 136 detailed categories (Additional file 1: Table ST-2).

Quotations from guidelines were used as raw data from which we generated summary information for individual criteria by combining similar elements (i.e. worksheet rows) and creating new text in a row above the raw data using a common language across guidelines (i.e. worksheet columns) for easier tracking of the process by which information was consolidated. This was condensed further into summary tables (Additional file 1: Tables ST-3-9) in which occurrences ("yes/no") of an indicator or action (typically at a "detailed" or "sub-detail level") were tabulated and summed $(i)$ within guidelines to indicate the breadth of a given guideline, and (ii) across guidelines to indicate the constancy of specific elements or actions. Given the differences between jurisdictions and regions of countries in culture, history, forestry sectors and renewable energy policies, we then created tables comparing the frequency of "yes/no" occurrences in North America and Europe (Tables 3, 4, 5, 7, 8, 10, 11).

\section{Results}

\section{Forest biomass harvesting guidelines}

We found 32 forest biomass harvesting guidelines (or related SFM guidelines or certification standards) that applied to all or part of 43 jurisdictions (Fig. 1; Table 2) in the USA (30), Canada (2), Europe (10) and East Asia (1), encompassing a total of 13 countries. All jurisdictions or regions with guidelines are within northern temperate and/or boreal forest regions; guidelines from Japan also address other forest types. Most guidelines were initially released or revised between 2008 and 2013 (Fig. 2). Jurisdictions and regions range in size from relatively small areas with relatively homogeneous forest landscapes or soils (e.g. Prince Edward Island, Netherlands) to larger areas with more diverse forest landscapes (e.g. regions in the USA). Guidelines generally apply to both privately and publicly owned forest land, but some only apply to public land (e.g. New Brunswick) or to private land (e.g. Vermont); some apply to both but are more stringent if renewable energy credits are sought (Massachusetts); and some are mandatory on public land but voluntary on private land (Denmark). Although most did not explicitly state that stakeholders were consulted or that scientific reviews were conducted as part of guideline development or revisions, others describe this in detail (e.g. Minnesota, Vermont, Wisconsin, Finland).

Most guidelines address removal of forest harvest residues from managed forests after final felling (with "residues" often left undefined). Some include whole-tree thinning (e.g. Austria, Denmark, Finland), while others (i.e. New Brunswick) explicitly exclude whole-tree chipping for pulpwood, although this also removes the equivalent of residues from stem-only harvesting. Japanese guidelines define what wood is acceptable (and requires certification) for their renewable energy feed-in tariff (FiT) program [52] without specifically addressing SFM practices. Some guidelines are relatively specific, but do not explicitly reference broader forest management governance (e.g. France).

A range of environmental sustainability (e.g. soil, biodiversity, water) and social topics (e.g. recreation, aesthetics, archaeology) are addressed in most guidelines. Other guidelines have a narrower focus; for example, those for France only address soil and site productivity; and those for the Netherlands specifically address removal of different amounts of forest biomass from stands of different species growing on sandy soils and resultant effects on available soil phosphorus, potassium, calcium and magnesium.

\section{General forest management}

Co-management for forest biomass and other tree components (e.g. merchantable stems) requires knowledge of what currently exists on-site and what stand characteristics are desired in the future, and then generating a plan to achieve this. Virtually all biomass harvesting 
Table 1 Hierarchical structure of the top two levels of information collected from forest biomass harvesting guidelines grouped within 8 general categories and 46 mid-level categories

\begin{tabular}{|c|c|c|c|}
\hline General categories $^{\mathrm{a}}$ & Mid-level categories & General categories & Mid-level categories \\
\hline \multirow[t]{12}{*}{ Meta-data } & & Soil & \\
\hline & Reference & & Sensitive soils \\
\hline & Queries & & Soil_other \\
\hline & Scope & & Compensation \\
\hline & Science background & & \\
\hline & Guideline development & Biodiversity & \\
\hline & Relationship to SFM ${ }^{b}$ & & Habitat protection \\
\hline & Applicable land & & Habitat retention \\
\hline & Strength & & Habitat enhancement \\
\hline & Monitoring & & Seasonality \\
\hline & Adaptive management & & \\
\hline & & Water and aquatic ecosystems & \\
\hline \multirow[t]{3}{*}{ Forest management } & & & Water quality \\
\hline & Forest management & & Leaching \\
\hline & & & Sedimentation \\
\hline \multirow[t]{16}{*}{ Forest biomass component } & & & Shade \\
\hline & Harvesting residue & & Riparian zones \\
\hline & Litter layer/forest floor & & Water flow \\
\hline & $F W D^{c}+$ foliage & & Exposed mineral soil \\
\hline & $C W D^{d}$ & & Contamination \\
\hline & DWM $^{e}$ & & Stream crossing \\
\hline & Large woody debris and logs & & Seasonality \\
\hline & Stumps & & Wetlands \\
\hline & Roots & & \\
\hline & Thinnings & Carbon/GHGs & \\
\hline & Live trees or patches of trees & & Carbon/GHGs \\
\hline & Live decaying trees & & \\
\hline & Snags & Social values & \\
\hline & Cavity trees & & Aesthetics/recreation \\
\hline & Mast trees & & Archaeology/history/culture \\
\hline & Den trees & & \\
\hline \multicolumn{4}{|c|}{$\begin{array}{l}\text { a See Additional file 1:Table ST-2, for complete hierarchy with additional } 136 \text { detailed categories and } 40 \text { sub-detailed categories extracted from Additional file 1:Table } \\
\text { ST-1 }\end{array}$} \\
\hline \multicolumn{4}{|l|}{ b Sustainable forest management } \\
\hline \multicolumn{4}{|l|}{${ }^{\mathrm{C}}$ Fine woody debris } \\
\hline \multicolumn{4}{|l|}{${ }^{d}$ Coarse woody debris } \\
\hline e Downed woody material & & & \\
\hline
\end{tabular}

guidelines note (i) the need for a pre-harvest inventory and management plan (Table 3; Additional file 1: Table ST-3), and (ii) that management for forest biomass harvesting can achieve specific objectives in addition to protection of soil, biodiversity, water and social values; these objectives most commonly include salvage logging, protection from or management of insect pests, diseases and invasive plants, and constraints imposed by avoidance of old-growth stands or application of different silvicultural systems (e.g. even- versus uneven-aged management) (Additional file 1: Table ST-3).

\section{Biodiversity}

Potential effects of forest biomass harvesting on biodiversity or habitat are noted in virtually all biomass harvesting guidelines or in general forestry guidelines or BMPs to which they are linked (Table 4; Additional file 1: Table ST-4). They emphasize restricting harvesting in or near habitats or sites of significant conservation value, in areas 

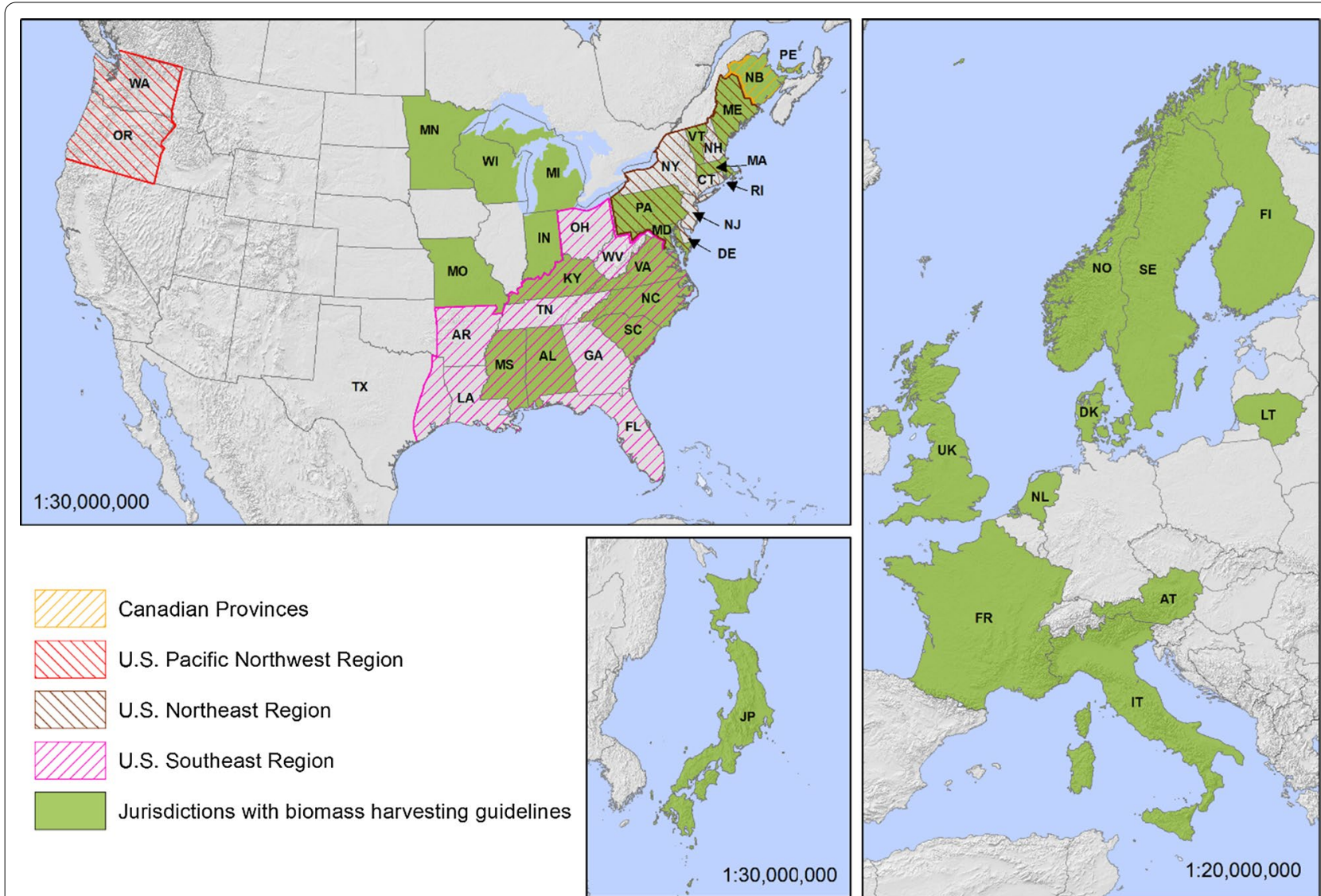

Fig. 1 Distribution of jurisdictions or regions with forest biomass harvesting guidelines, or related SFM guidelines or certification standards. (See Table 2 for key to two-letter jurisdiction codes. Shaded relief and administrative boundaries by Natural Earth, available at http://www.naturalear thdata.com/.)

containing "endangered" or "threatened" species, and in wetlands. Recommendations typically fall within the context of stricter regulations or certification schemes (e.g. FSC, PEFC). In Finland, good practice guidelines recommend that forest biomass harvesting occur outside of areas listed under nature protection and forest laws and certificates. In the USA, sites of significant conservation value may vary in the degree to which harvesting is permitted; for instance, those containing species designated as threatened or endangered have federal and state protections that do not apply to other sensitive ecosystems. Terms for sites with important conservation values vary in US guidelines and include "significant natural communities" (Vermont), "high-quality natural communities (Indiana, Michigan), "features of high conservation value" (Missouri), "special management areas" (Maine), "sensitive sites" (Indiana, Kentucky, Michigan), "sensitive areas" (Minnesota, South Carolina), "sensitive habitats" (Pennsylvania), "sensitive natural communities" (Wisconsin), and "rare and sensitive forest types" (Maryland), where "sensitive" indicates a combination of site rarity and threat of damage from forest management. Most guidelines provide examples and links to sources of more detailed information, typically an associated natural features database.

Approaches recommended for maintaining or improving biodiversity (Table 4) include (i) retention of forest biomass with critical habitat value, whether live or dead (e.g. den or cavity trees, mast- (nut- and fruit-) producing woody vegetation critical for wildlife, snags, and large downed coarse woody debris); (ii) retention of harvest residues (piled or scattered) used by wildlife; (iii) retention of travel corridors for wildlife, and (iv) avoiding harvesting during key breeding or migratory periods. Nine of the 25 guidelines provide minimum retention thresholds for snags, den trees or cavity trees (Additional file 1: Table ST-5). Three guidelines (Pennsylvania, Wisconsin, Northeast USA) note the importance of the forest floor as important habitat for microorganisms, fungi and beneficial insects which, in turn, affect soil productivity. North American and European guidelines have similar numbers of potential 
Table 2 Jurisdictions (countries, states or provinces) or regions within a country with forest biomass harvesting guidelines

\begin{tabular}{|c|c|c|c|c|c|}
\hline \multirow[t]{2}{*}{ Code $^{a}$} & \multirow[t]{2}{*}{ Jurisdiction } & \multicolumn{2}{|c|}{ Guideline $^{b}$} & \multirow[t]{2}{*}{ Code } & \multirow[t]{2}{*}{ Jurisdiction } \\
\hline & & State & Region $^{c}$ & & \\
\hline USA & & & & Canada & \\
\hline $\mathrm{AL}$ & Alabama & State & SE-USA & NB & New Brunswick \\
\hline$A R$ & Arkansas & & SE-USA & PE & Prince Edward Island \\
\hline $\mathrm{DE}$ & Delaware (also in SE) & & NE-USA & & \\
\hline DE & Delaware (also in NE) & & SE-USA & Europe & \\
\hline $\mathrm{FL}$ & Florida & & SE-USA & $A T^{b}$ & Austria \\
\hline GA & Georgia & & SE-USA & DK & Denmark \\
\hline IN & Indiana & State & & $\mathrm{Fl}$ & Finland \\
\hline KY & Kentucky & State & SE-USA & FR & France \\
\hline LA & Louisiana & & SE-USA & & \\
\hline MA & Massachusetts & State & NE-USA & $\mathrm{IT}^{\mathrm{b}}$ & Italy \\
\hline MD & Maryland (also in SE) & State & NE-USA & $\mathrm{LT}^{\mathrm{b}}$ & Lithuania \\
\hline $\mathrm{MD}$ & Maryland (also in NE) & State & SE-USA & $\mathrm{NL}$ & Netherlands \\
\hline ME & Maine & State & NE-USA & $\mathrm{NO}^{\mathrm{b}}$ & Norway \\
\hline $\mathrm{Ml}$ & Michigan & State & & SE & Sweden \\
\hline $\mathrm{MN}$ & Minnesota & State & & $U K^{d}$ & United Kingdom \\
\hline $\mathrm{MO}$ & Missouri & State & & & \\
\hline MS & Mississippi & State & SE-USA & SEAsia & \\
\hline NC & North Carolina & State & SE-USA & $J P^{b}$ & Japan \\
\hline $\mathrm{NH}$ & New Hampshire & & NE-USA & & \\
\hline NJ & New Jersey (also in SE) & & NE-USA & & \\
\hline NJ & New Jersey (also in NE) & & SE-USA & & \\
\hline NY & New York & & NE-USA & & \\
\hline $\mathrm{OH}$ & Ohio & & SE-USA & & \\
\hline OR & Oregon & & PNW-USA & & \\
\hline PA & Pennsylvania & State & NE-USA & & \\
\hline SC & South Carolina & State & SE-USA & & \\
\hline $\mathrm{TN}$ & Tennessee & & SE-USA & & \\
\hline TX & Texas (eastern TXonly) & & SE-USA & & \\
\hline VA & Virginia & State & SE-USA & & \\
\hline VT & Vermont & State & NE-USA & & \\
\hline WA & Washington & & PNW-USA & & \\
\hline WI & Wisconsin & State & & & \\
\hline WV & West Virginia & & SE-USA & & \\
\hline
\end{tabular}

a Jurisdictions are sorted within major global regions by two-letter country codes (ISO 3166, except for UK), state codes for the USA (ANSI), and Canadian provincial codes (Canada Post)

b Guidelines for Austria, Italy Lithuania, Norway and Japan are from forest management guidelines or certification standards, and are included to expand the breadth of OECD countries covered

c Codes are for the Northeast of the USA (NE-USA), the Southeast of the USA (SE-USA) and the Pacific Northwest of the USA (PNW-USA)

d The United Kingdom of Great Britain and Northern Ireland is represented by "UK" because "GB" (as used in ISO) is commonly used for Great Britain alone, and the UK Forestry Standard applies to the entire UK

actions for maintaining biodiversity (Table 4; Additional file 1: Table ST-4).

\section{Sensitive soils and sites}

Forest biomass harvesting can reduce soil productivity if soil fertility decreases, soil acidity increases, soil erodes, or soil structure, moisture retention and aeration are altered. Guidelines provide various combinations of (i) use of indicators (and their threshold levels) of soils and sites prone to damage; (ii) information about consequences of damage (e.g. decreased productivity) and (iii) suggested actions to mitigate soil damage (Table 5; Additional file 1: Table ST-6). Indicators vary in how much they integrate soil and site characteristics, with some 


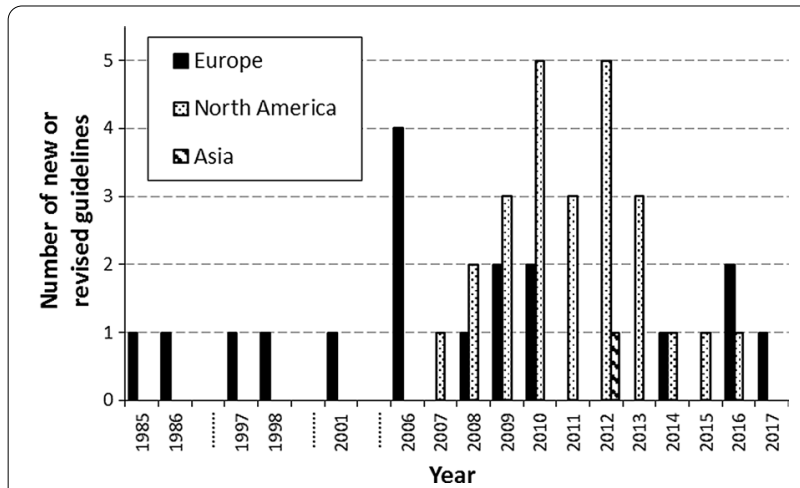

Fig. 2 Number of new or revised forest biomass harvesting guidelines released by year in European and North American jurisdictions and regions (from Additional file 1: Table ST-1 and from the literature). Jurisdictions with revised guidelines include Finland (2006, 2010, 2014, 2016 work guide), Massachusetts (2012, 2013 2nd edition), Michigan (2010, 2012 stand retention at harvesting), Minnesota (2007, 2013), Norway (1998, 2008, 2016 PEFC standard), Sweden $(1986,2001,2008)$, the UK $(1997,2009)$ and Wisconsin $(2009$, 2014)

Table 3 Forest management topics addressed in forest biomass harvesting guidelines, as percent occurrence in 21 North American and 10 European jurisdictions or regions

\begin{tabular}{lll}
\hline Action or practice $^{\text {a }}$ & North America & Europe \\
\hline General forest practice (any action) & 100 & 80 \\
Inventory resources & 90 & 70 \\
Create pre-harvest management plan & 95 & 50 \\
Close-out procedures $^{\text {b }}$ & 24 & 0 \\
Biomass and forest management (any action) & 95 & 90 \\
Restrict harvest in old growth & 48 & 60 \\
Even- or uneven-aged stand management & 52 & 90 \\
"High-grading" or diameter-limit cutting & 24 & 10 \\
Damage to remaining trees & 33 & 40 \\
Regeneration & 38 & 10 \\
Reduction of fuels for wildfire & 43 & 10 \\
Burning post-harvest residue & 14 & 50 \\
Diseases, pests or invasive species & 67 & 40 \\
Salvage logging & 76 & 30 \\
Conversion to plantations & 48 & 10 \\
\hline
\end{tabular}

a See Additional file 1: Table ST-3 for more detail

b Procedures that ensure that forest operation is brought to completion, such as final inspection, documentation, etc.

representing a high degree of integration (e.g. site type) and some a low degree of integration (e.g. use of single measurable characteristics on their own, such as slope, soil texture or soil depth). Indicators may relate directly to a specific concern (e.g. nutrient availability and potential for soil nutrient depletion), or infer susceptibility to multiple concerns (e.g. soil texture can indicate the levels
Table 4 Biodiversity topics addressed in forest biomass harvesting guidelines, as percent occurrence in 21 North American and 10 European jurisdictions or regions

\begin{tabular}{|c|c|c|}
\hline Action or practice ${ }^{a}$ & $\begin{array}{l}\text { North } \\
\text { America }\end{array}$ & Europe \\
\hline Biodiversity (any action) & 91 & 80 \\
\hline Restrict on valuable or sensitive sites & 90 & 80 \\
\hline $\begin{array}{l}\text { Restrict on sites with threatened or endangered } \\
\text { species }\end{array}$ & 90 & 70 \\
\hline $\begin{array}{l}\text { Retain some standing live and dead trees, fallen } \\
\text { woody biomass, stumps/roots (see also Tables } 6 \\
\text { and 7) }\end{array}$ & 90 & 70 \\
\hline Retain mast-producing woody vegetation ${ }^{\mathrm{b}}$ & 48 & 40 \\
\hline Retain forest floor or litter (see also Table 8) & 90 & 30 \\
\hline $\begin{array}{l}\text { Retain harvest residues used by wild life (not in } \\
\text { Table 8) }\end{array}$ & 29 & 10 \\
\hline Retain travel corridors and transition areas & 33 & 20 \\
\hline Avoid harvest during reproduction, migration & 24 & 40 \\
\hline $\begin{array}{l}\text { Encourage native species or discourage non- } \\
\text { natives }\end{array}$ & 52 & 50 \\
\hline
\end{tabular}

a See Additional file 1: Table ST-4 for more detail

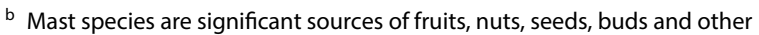
tissues high in proteins, carbohydrates and fats (Minnesota guidelines, 2012 edition published in 2013)

of susceptibility to soil compaction and erosion, increase in acidification, reduction in nutrient availability, and potential for water-holding capacity).

\section{Integrated indicators of sensitive soils}

Indicators used to identify sensitive soils or sites prone to physical damage or nutrient depletion commonly integrate a number of soil properties. These indicators include (i) soil type (Massachusetts, Wisconsin, UK, France, Netherlands); (ii) site type or ecological classification system (Austria, Finland, Lithuania); (iii) drainage classes and soil erosion hazard (Maine); or (iv) soil expert systems (South Carolina) or GIS-based decision support tools (New Brunswick, Maryland, Pacific Northwest USA). Some jurisdictions or regions do not define "sensitive" soils (or sites), in which case local knowledge is integrated to make decisions.

\section{Individual indicators of sensitive soils: physical characteristics} Physical indicators of soil or site sensitivity to forest biomass harvesting include steep slopes, coarse textures, shallow soils and soil moisture content (including dry, wet, or both) (Table 5; Additional file 1: Table ST-6). Threshold levels for slope, soil texture and soil depth beyond which site or soil damage may occur are specified most frequently in American guidelines (Table 6). Slope steepness (along with soil texture, slope length, soil moisture content and soil organic matter content) contributes 
Table 5 Soil sensitivity topics (including indicators of sensitive sites, recommended actions, and potential consequences of not taking actions) addressed in forest biomass harvesting guidelines, as percent occurrence in 21 North American and 10 European jurisdictions or regions

\begin{tabular}{|c|c|c|}
\hline Indicator, consequence or action ${ }^{a}$ & North America & Europe \\
\hline \multicolumn{3}{|l|}{ Integrated site indicators } \\
\hline Site classification, soil survey, expert system, etc. & 86 & 90 \\
\hline \multicolumn{3}{|l|}{ Specific-site indicators } \\
\hline Slope & 86 & 30 \\
\hline Soil texture & 62 & 50 \\
\hline Soil depth & 62 & 10 \\
\hline \multicolumn{3}{|l|}{ Soil moisture } \\
\hline Dry soil or site & 48 & 40 \\
\hline Poorly drained, or wetland, or organic soil & 57 & 40 \\
\hline Soil organic matter & 14 & 10 \\
\hline Soil fertility & 62 & 90 \\
\hline \multicolumn{3}{|l|}{ Soil physical damage } \\
\hline \multicolumn{3}{|l|}{ Consequences } \\
\hline Erosion, mass wasting, or displacement & 100 & 70 \\
\hline Compaction or rutting & 86 & 80 \\
\hline Soil disturbance ${ }^{b}$ & 52 & 30 \\
\hline \multicolumn{3}{|l|}{ Actions } \\
\hline Restrict residue removal on steep slopes & 76 & 50 \\
\hline Minimize area of landings, roads, trails & 81 & 30 \\
\hline Restrict residue removal to dry or frozen soils & 71 & 50 \\
\hline Restrict number of entries/passes & 43 & 40 \\
\hline Retain harvest residue (see Table 9) & 90 & 80 \\
\hline Use appropriate equipment & 38 & 30 \\
\hline Reduce amount of harvest residue removed & 14 & 0 \\
\hline \multicolumn{3}{|l|}{ Soil fertility } \\
\hline \multicolumn{3}{|l|}{ Consequences } \\
\hline Loss of nutrients & 90 & 100 \\
\hline \multicolumn{3}{|l|}{ Actions } \\
\hline Restrict residue removal on shallow soils & 67 & 30 \\
\hline Restrict residue removal on rocky, stony areas & 10 & 20 \\
\hline Restrict residue removal on low-fertility soils & 38 & 90 \\
\hline $\begin{array}{l}\text { Restrict residue removal on weathered soils, or soils with low buffering capacity, or acid- } \\
\text { sensitive or highly acidic soils }\end{array}$ & 10 & 30 \\
\hline Restrict residue removal on organic soils & 62 & 40 \\
\hline Restrict residue removal on sandy soils & 38 & 50 \\
\hline Retain harvest residue (see Table 9) & 100 & 100 \\
\hline
\end{tabular}

a See Additional file 1: Table ST-6 for more detail

b See Table 10 re: soil contamination and potential impacts on water and aquatic ecosystems

to erosion (e.g. [53]). Slope gradient thresholds are defined in 11 guidelines ${ }^{1}$ and range from $20 \%$ (Vermont) to 50\% (Pacific Northwest USA). Massachusetts combines slope steepness with slope length. Maryland assigns

\footnotetext{
${ }^{1}$ Indiana identifies steep slope threshold in an associated document not referenced in guidelines.
}

a maximum sensitivity weighting to slopes greater than $20 \%$, but suggests that the importance of slope to site sensitivity is small compared to available water-holding capacity (AWC) and soil organic matter content [54].

All biomass harvesting guidelines which use soil texture as an indicator consider coarse-textured soils (e.g. sandy, rocky or stony; or skeletal in the UK) to be of low-productivity and hence prone to decreases in soil 
Table 6 Physical indicators of sites sensitive to forest biomass harvesting

\begin{tabular}{|c|c|c|c|c|}
\hline \multicolumn{2}{|l|}{ Jurisdiction } & \multirow[t]{2}{*}{ Slope $(\% \text { gradient })^{b}$} & \multirow[t]{2}{*}{ Soil texture } & \multirow[t]{2}{*}{ Soil depth $(\mathrm{cm})$} \\
\hline Code $^{\mathrm{a}}$ & Name & & & \\
\hline NB & New Brunswick & & R & $<30$ \\
\hline$A L$ & Alabama & & s & \\
\hline IN & Indiana & $>20 \%$ & & \\
\hline MA & Massachusetts & $>30 \%$ & S & $<51$ \\
\hline MD & Maryland & $>20 \%,>40 \%$ & S & $<51$ \\
\hline ME & Maine & & $\cos$ & $<30$ \\
\hline $\mathrm{MN}$ & Minnesota & $>35 \%$ & S & $<51$ \\
\hline $\mathrm{MO}$ & Missouri & $>35 \%$ & & $<51$ \\
\hline MS & Mississippi & $>35 \%$ & $S(>60 \%)$ & $<60($ A hrzn $<8)$ \\
\hline PA & Pennsylvania & $>40 \%$ & & \\
\hline SC & South Carolina & $>30 \%$ & $\mathrm{~S}(>80 \%) ; \mathrm{R}$ & $<50$ \\
\hline $\mathrm{VT}$ & Vermont & $>20 \%$ & & \\
\hline Wl & Wisconsin & & S & $<51$ \\
\hline NE-USA & Northeast USA & & S & \\
\hline PNW-USA ${ }^{C}$ & Pacific Northwest USA & Steep & & \\
\hline UK & UK & & S, skeletal & $<35-45$ \\
\hline FR & France & & S-LS, SL & \\
\hline $\mathrm{NL}$ & Netherlands & & S & \\
\hline DK & Denmark & & S & \\
\hline $\mathrm{Fl}$ & Finland & & R & \\
\hline$L T^{d}$ & Lithuania & $>100 \%$ & & \\
\hline
\end{tabular}

a Jurisdictions in same order as in Additional file 1: Table ST-1

b Slopes typically reported as gradient (i.e. $x / y$, or rise-over-run, expressed as $x$ as a percentage of $y$ ); no gradient given for PNW-USA (Pacific Northwest USA)

$S$ sand, $C O S$ coarse sand, $R$ rocky or stony, LS loamy sand, SL sandy loam

IN (Indiana) inferred from associated document

c PNW-USA (Pacific Northwest USA): retain $>30 \%$ of harvest residue on slopes suitable for ground-based harvesting; retain $>50 \%$ on steeper slopes in the Douglas-fir region

${ }^{d}$ Clearcutting not permitted in LT (Lithuania) on slopes $>45^{\circ}(=100 \%$ slope)

fertility if intensively harvested. "Sandy" and "coarsetextured" are often combined with the descriptors "dry" or "droughty", and with "nutrient-poor". Conversely, "littoral" (coastal sand and gravel) soils in the UK are considered at high risk of nutrient loss with forest biomass harvesting, but range from excessively drained (very dry) to wet [55]; the latter are also prone to ground damage from harvesting [56]. Soil texture may indicate potential sensitivity of soils to damage from erosion, compaction, and rutting. Wisconsin and Minnesota guidelines note that erosion is potentially greater in finer-textured (e.g. silty) than coarser-textured soils. In some US states, relationships between soil texture and erosion (Michigan) or compaction (South Carolina) are noted in separate state forestry BMPs, but not specifically in biomass harvesting guidelines.

Shallow soils have less nutrient- and water-holding capacity and may be more prone to compaction, rutting and erosion than deeper soils (Wisconsin [57]). Depths which define shallow soils (Table 6) range from $<30 \mathrm{~cm}$
(New Brunswick, Maine) to $60 \mathrm{~cm}$ (Mississippi). In five US states, soils $<51-\mathrm{cm}$ (20-inches) deep are considered shallow for forest biomass harvesting purposes; this is consistent with the definition for shallow soils (25$50 \mathrm{~cm}$ ) in US soil surveys [58]. Three guidelines (Michigan, Vermont, Southeast USA) note the importance of soil depth, but do not specify the depths at which this becomes problematic, or reference where this information may be found.

Biomass harvesting guidelines often recommend restricting removals from "dry" sites (Additional file 1: Table ST-6), for which definitions and descriptions can vary. In Finland, dry (xeric) upland site types are identified by understory vegetation composition that indicates site fertility [59] and are considered unsuitable for removal of harvest residues. Massachusetts and Maine apply Natural Resources Conservation Service (NRCS) drainage classes [58] and suggest caution when soils are "well-drained" and "excessively drained", respectively. These drainage classes are generally associated with 
coarse soil textures and high saturated hydraulic conductivity or are very shallow [58] and have been related to forest site productivity class in Maine, where they can be identified in the field based on soil characteristics [60]. Wisconsin guidelines suggest dry nutrient-poor sandy soils have "drainage classes that indicate dry conditions" and list the relevant soil map units, but do not define "dry" or explain its significance to site sensitivity; the primary concern is likely that such soils lack nutrients and have high leaching rates. Available water-holding capacity of soil varies with soil texture, soil organic matter content, bulk density and soil structure [61], and low AWC is used to indicate dry soils in three state guidelines (Maryland, Mississippi, South Carolina). In Maryland, AWC $<0.1 \mathrm{~cm} \mathrm{~cm}^{-1}$ (within soil depths of up to $51 \mathrm{~cm}$ ) is considered to indicate sites more prone to damage from forest biomass harvesting. In South Carolina and Mississippi, total AWC $<14 \mathrm{~cm}$ for the soil profile (regardless of soil depth) indicates sites with "very limited" potential for sustainable forest biomass harvesting. "Very limited" sites in South Carolina also have a maximum root restriction depth of $50 \mathrm{~cm}$. On the other hand, detailed descriptions and definitions of "dry" sites are not always provided in guidelines, such as for "dry and poor" sites in New Brunswick, and "droughty sands" in Minnesota.

Definitions of wet or organic soils and the concerns associated with harvesting forest biomass on them also vary. In two guidelines (South Carolina, Mississippi), wet sites with a water table depth of $<30 \mathrm{~cm}$ and organic matter content $>10 \%$ are considered very unsuitable for biomass harvesting. Three guidelines (Massachusetts, Wisconsin, UK) identify specific wet-site soil types as relatively unsuitable for harvesting, with an emphasis on maintaining site fertility (Wisconsin) or minimizing ground damage or fertility decreases (UK), depending on the site and soil type. Other guidelines contain generalized descriptions of problematic wet sites and discourage harvesting on them because of possible damage to soil structure, water quality or valuable habitat (see also Table 4; Additional file 1: Table ST-6).

\section{Individual indicators of sensitive soils: chemical characteristics}

Forest biomass harvesting can decrease soil fertility by depleting site nutrient capital, by preferentially removing cations and gradually acidifying soil, or through soil disturbance (including erosion, soil displacement, compaction, and rutting). Guidelines describe sites and soils prone to nutrient depletion in many ways. Descriptors include (i) a general lack of nutrients, e.g. "nutrientpoor" (Massachusetts) or "low-fertility" (South Carolina, Vermont); (ii) reduced nutrient inputs ("ombrotrophic organic soils" (Minnesota), and (iii) soil acidity, e.g. "low buffering capacity" and "highly acidic" (Maryland), and "vulnerable to acidification" (UK). These properties are often not determined directly from soil chemical analyses, but indirectly from soil physical properties (such as texture), vegetation (Finland, France), or soil classification (Wisconsin, UK) which, in turn, relies partly on soil chemical analyses.

Soil cation exchange capacity (CEC) is the net negative charge on soil organic matter (SOM) and clay particles, and determines a soil's ability to retain cation nutrients (e.g. $\mathrm{NH}_{4}-\mathrm{N}, \mathrm{K}, \mathrm{Ca}, \mathrm{Mg}$ ) and hence soil fertility; SOM typically has a higher CEC than clays. Three guidelines link soil CEC to site suitability for forest biomass harvesting. In Mississippi, suitability for forest biomass harvesting with CEC ranges from slightly limiting $\left(>10 \mathrm{cmol} \mathrm{kg}^{-1}\right)$, to moderately limiting $\left(5-10 \mathrm{cmol} \mathrm{kg}^{-1}\right)$, to very limiting $\left(<5 \mathrm{cmol} \mathrm{kg}^{-1}\right)$. In South Carolina, sites with CEC of $5-10 \mathrm{cmol} \mathrm{kg}^{-1}$ are considered suitable, those with $0-5$ cmol kg $\mathrm{kg}^{-1}$ or $10-20 \mathrm{cmol} \mathrm{kg}^{-1}$ are moderately suitable, and those with $>20 \mathrm{cmol} \mathrm{kg}^{-1} \mathrm{CEC}$ are very limited in capacity for biomass harvesting although CEC is greatest, and reasons for this limitation with high CEC are not explained. Biomass harvesting guidelines for Massachusetts indicate that soils with a low CEC of $3-4^{2}$ meq $\mathrm{L}^{-1}$ have "poor" suitability [62], although CEC is normally expressed in meq per $100 \mathrm{~g}$ soil (or its equivalent, cmol $\mathrm{kg}^{-1}$ ) [61]. More importantly for practitioners, however, Massachusetts lists soil units classified as nutrient-poor and requires soil maps of harvest areas when renewable energy credits for forest biomass are sought. Biomass harvesting guidelines subsequently incorporated into the Massachusetts forestry BMP simply describe "poor soil" as "poor, according to USDA NRCS standards" and includes "nutrient-poor sands with low nutrient capacity" [63]. In Maryland, sites with "highly acidic" (sic) soils may be inappropriate for forest biomass harvests, but the term is undefined and inconsistent with standardized definitions [61]; such sites have "low to moderate base saturation $(\mathrm{pH}<4.5)$ " [54]. The focus in the UK is on the "acid-base status" of the underlying soil type when determining site sensitivity to forest biomass removal, and soils with high acidity and low base status are therefore placed in a "high-risk" category because of potential base cation nutrient deficiency.

Low soil organic matter (SOM) content may indicate inadequate soil moisture or nutrient availability (related to nutrient mineralisation rate and CEC). Soils are considered very limiting for forest biomass harvesting if SOM is $<1 \%$ (Maryland, Mississippi, South Carolina);

\footnotetext{
${ }^{2}$ Conversion of meq $\mathrm{L}^{-1}$ to SI units for comparison was not possible because of lack of bulk density data.
} 
slightly to moderately limiting if SOM is $2-10 \%$ (South Carolina), slightly limiting if SOM is $3-5 \%$ (Mississippi), and moderately limiting if SOM is $>3 \%$ (Mississippi). At the other end of the spectrum, organic soils have high SOM but forest biomass harvesting is also not recommended where rain is the main source of nutrients (i.e. ombrotrophic peats) and hence fertility is low, regardless of CEC (e.g. dysic Histosols in Massachusetts, Minnesota, Pennsylvania, Wisconsin; some peats in the UK). Whether organic matter is "friend or foe" depends on the ecosystem [64].

\section{Physical damage to soil and mitigation options}

Erosion and mass wasting may reduce soil productivity through topsoil loss, and compaction and rutting may decrease soil moisture retention and aeration and increase erosion. All these impacts may ultimately reduce water quality, and the need to minimize soil loss and physical damage is emphasized within biomass harvesting guidelines or associated broader forest management guidelines and BMPs. Most guidelines address both soil physical damage and soil loss from sites.

Soil disturbance terminology and indicators and their thresholds for soil vulnerability vary. Extra caution is suggested when harvesting biomass on "erodible" (Kentucky, Missouri), "highly erodible" (Indiana, Pennsylvania, South Carolina), and "erosion-prone" (Maryland, Maine, Minnesota) sites. Approximately $30 \%$ of guidelines provide a definition, threshold, or list of soil units most prone to erosion (e.g. Table 6). Erosion-prone sites include those with slopes $>40 \%$ and exposed mineral soil (Maryland); and those with steep (>30\%) slopes or "highly erodible" soils, for which a "K" value (i.e. soil erodibility factor [53]) is provided (South Carolina). Most guidelines that advise restricting harvests on "erodible" or "highly erodible" soils neither define the terms nor provide links to references which do; however, Michigan and Minnesota note associated soil and site characteristics. Compaction and rutting are occasionally noted to be more likely in wet than in dry soils, and in fine-textured than in coarser-textured soils. Harvesting should be modified to reduce rutting in at least five jurisdictions if specified rut sizes are exceeded: $>20-\mathrm{cm}$ depth in Indiana; $>15-\mathrm{cm}$ depth for a length greater than ca. $15 \mathrm{~m}$ in Missouri; $>25$-cm depth in Vermont; $>10$-cm depth for $>5 \%$ of the rut length on the site in Finland; and $>10-\mathrm{cm}$ depth and $>5 \mathrm{~m}$ in length in the UK, where forest biomass removal by skidder is recommended on flat ground, by forwarder on moderate slopes, and by cable crane on steep slopes.

To minimize erosion, compaction, or rutting, guidelines most often suggest harvesting only when soils are dry or frozen, restricting the number or frequency of entries, and retaining harvest residue on skid trails and throughout the harvest site. Actions less commonly suggested include using different felling and removal techniques, or reducing the number of trees harvested.

\section{Fertility loss and mitigation options}

Nutrient removal from sites can be reduced by retaining more forest biomass on soils with limited rooting volume (shallow or rocky soils) or low nutrient availability per unit of soil (sandy soils), adjusting removal rates based on tree species, and minimizing removal of litter and the forest floor. Delaying removal of forest biomass until needle shedding after a drying period (cf. [65]) is recommended in the UK because needles contain about half to two-thirds of the total nutrients in all the biomass; the length of drying period required depends on local climate and time of year, and typically ranges from 3 to 9 months. Similarly, deciduous broadleaved trees can be harvested after autumn leaf-fall. Harvesting restrictions were suggested more often for shallow soils (Missouri; Vermont in relation to soil disturbance) than for rocky soils (Additional file 1: Table ST-6). Guidelines may recommend different harvesting intensities and frequencies for coniferous than for deciduous species, depending on site fertility (e.g. Denmark, France, Massachusetts, Maryland, Minnesota, Netherlands); removing harvest residues of aspen and birch is explicitly discouraged on nutrientpoor shallow soils in Minnesota, while harvesting from jack pine and red pine is explicitly allowed on dry nutrient-poor sandy soils in Wisconsin. Avoiding whole-tree thinning when more than $75 \%$ of stems in stands are Norway spruce is recommended in Finland because of potential growth reductions leading to reduced stem volume compared to stem-only harvesting [66]. Lengthening rotations may increase quantities of downed woody material (Pacific Northwest USA) and needle fall, and hence help compensate for site productivity impacts.

\section{Compensatory actions for soils and biodiversity}

Compensatory actions can help restore desired site characteristics if guidance to avoid or mitigate harvesting impacts was not sufficient to prevent undesirable environmental outcomes. This generally means applying wood ash and/or fertilizer to restore site fertility and reduce soil acidity but can also include restoration of other affected soil properties or whole ecosystems, increasing rotation length between final harvesting of stands to increase total organic matter input (litterfall, CWD) over a rotation, and creating high stumps at felling as habitat.

Compensatory application of combustion wood ash and/or fertilizer is mentioned more frequently and in more detail in European than in North American guidelines (Table 7). The UK Forestry Standards [34, 
Table 7 Compensatory actions to replace harvested nutrients (i.e. application of ash or fertilizer) in forest biomass harvesting guidelines, as percent occurrence in 21 North American and 10 European jurisdictions or regions

\begin{tabular}{lll}
\hline Action or detail $^{\mathrm{a}}$ & North America & Europe \\
\hline Ash application & & 70 \\
Rationale & 5 & 50 \\
Ash type $^{b}$ & 0 & 30 \\
Nutrient concentration (minimum content) $_{\text {Contaminant concentration (maximum allowed) }}$ & 0 & 60 \\
Ash application rate & 0 & 60 \\
Appropriate sites & 0 & 70 \\
Inappropriate sites or timing of application & 0 & 70 \\
Fertilizer application & & 70 \\
Treatment is mentioned & 19 & 70 \\
Appropriate sites & 5 & 40 \\
Inappropriate sites & 5 & 40 \\
Elements in fertilizer, or fertilizer application rate & 5 & \\
\hline
\end{tabular}

a See Additional file 1: Table ST-9 for more details

b Ash type: bottom, fly, granulated, hardened, etc.

67] indicate that limited amounts of wood ash can be applied to non-agricultural soils (up to $1 \mathrm{t} \mathrm{ha}^{-1}$ year $^{-1}$ of ash from small wood-chip boilers $[68,69]$ ) but the ash must provide a benefit to soil, and the treatment must be assessed for suitability for the site and soil, costeffectiveness and environmental sustainability. Other European guidelines or regulations regarding ash (Austria, Denmark, Lithuania, Sweden) may be separate from biomass harvesting guidelines (e.g. Austria, Denmark) and contain more detail by addressing recommended or required ash characteristics, maximum contaminant concentrations, appropriate application rates for different sites, and where and when ash should not be applied [50, 70, 71] (Additional file 1: Table ST-9). In Norway, "any ash spreading in forests must take place in compliance with the regulation on fertilisers, etc., of organic origin" which, in effect, prohibits the spreading of ash because this condition cannot be met in practice. In Austria, ash from forest biomass may be applied to increase $\mathrm{pH}$ values and base cation supply if a positive impact can be expected and if contaminant levels do not exceed defined thresholds. South Carolina biomass harvesting guidelines recommend "amelioration with...ash...where nutrient depletion is a concern", but state regulations concerning ash applications to land [72] are not cited in the guidelines or Best Management Practices for Forestry.

Guidelines from France, Denmark, Norway, Sweden and Finland suggest circumstances when compensatory fertilization is or is not appropriate. Earlier UK guidelines suggest that whole-tree harvesting on sites considered high-risk because of potential nutrient loss may require remedial fertilization [56], or application of limestone or wood ash [73]; later guidelines [67] suggest that compensatory fertilization should be a "last resort in sustainable forestry", and discourage its use around water and special sites. Austria also lists situations where compensatory fertilization is inappropriate, including in areas sensitive to water pollution, in riparian zones, on sites with shallow soils, and in nature reserves.

Compensatory fertilization is mentioned in guidelines for four American states (Alabama, Maryland, Minnesota, South Carolina), but specific recommendations are not given. Fertilization of "naturally regenerating mixed-hardwood forests" is discouraged in Maryland; and Minnesota's guidelines indicate that sites that have been whole-tree harvested may need corrective fertilization but note that research data are limited and recommendations need to be refined. The South Carolina BMP for Forestry indicates situations where phosphorus and nitrogen additions might be needed.

Extending rotations to increase forest floor buildup and thus replenish nutrients between fellings can also be used to compensate for nutrient loss, but is typically treated as a precautionary measure (Missouri, North Carolina, Vermont, Italy), or its corollary (i.e. not shortening rotations; Virginia). The benefits to soil, water quality and biodiversity are also noted, even if no explicit recommendations are given (Indiana, Maine, Pacific Northwest, Austria), except for stands producing mast for wildlife (Missouri).

Related to biodiversity, creation of high stumps has been suggested as a compensatory action for harvest residue removal [74], and Norwegian guidelines recommend retaining "natural high stumps". 
Table 8 Biomass retention topics addressed in forest biomass harvesting guidelines, as percent occurrence in 21 North American and 10 European jurisdictions or regions

\begin{tabular}{|c|c|c|}
\hline Indicator, component to retain, or action ${ }^{\mathrm{a}}$ & North America & Europe \\
\hline \multicolumn{3}{|l|}{ Evaluate } \\
\hline \multicolumn{3}{|l|}{ Indicator } \\
\hline Site/soil & 67 & 70 \\
\hline Existing DWM ${ }^{b}$ & 33 & 30 \\
\hline Dominant species & 19 & 30 \\
\hline Forest management objectives (e.g. harvest frequency and intensity, regeneration) & 57 & 30 \\
\hline \multicolumn{3}{|l|}{ What to retain } \\
\hline \multicolumn{3}{|l|}{ Pre-harvest-live material } \\
\hline Live decaying, or cavity trees, or nest trees & 62 & 50 \\
\hline Mast trees & 48 & 30 \\
\hline Den trees & 43 & 10 \\
\hline Residual patches of trees & 48 & 40 \\
\hline Residual trees (distribution, etc., not specified) & 10 & 30 \\
\hline \multicolumn{3}{|l|}{ Pre-harvest_-dead material } \\
\hline Snags & 86 & 60 \\
\hline Cut snags & 48 & 0 \\
\hline$C W D_{1}^{c}$ logs & 76 & 60 \\
\hline$F W D^{d}$ & 57 & 30 \\
\hline Forest floor or litter & 86 & 20 \\
\hline \multicolumn{3}{|l|}{ Post-harvest ${ }^{\mathrm{e}}$} \\
\hline Harvest residue & 100 & 70 \\
\hline FWD & 90 & 50 \\
\hline CWD, DWM, woody debris, logs & 57 & 30 \\
\hline Stumps and coarse roots & 90 & 70 \\
\hline \multicolumn{3}{|l|}{ How to retain } \\
\hline Harvest after leaf drop & 57 & 30 \\
\hline Let foliage "cure" before removing biomass & 14 & 40 \\
\hline Lengthen rotations & 38 & 40 \\
\hline Partial cut or thinning & 48 & 60 \\
\hline Remove stems only & 52 & 60 \\
\hline Retain normal breakage from harvest & 19 & 10 \\
\hline Return residue from roadside & 38 & 0 \\
\hline Distribute residue on-site or increase residue amounts & 95 & 50 \\
\hline
\end{tabular}

a See Additional file 1: Table ST-5 for more detail

b DWM: downed woody material

c CWD: coarse woody debris

d FWD: fine woody debris

e See Table 9 for harvest residue retention thresholds

\section{Amount of forest biomass to retain}

As indicated above, retention of a proportion of forest harvest residues (i.e. tops, branches, foliage) can reduce direct harvesting impacts. Other types of forest biomass can also be retained, including standing live or dead trees, pre-existing downed wood, the forest floor, and stumps and roots, all of which can mitigate a range of undesirable impacts, including those on habitat quality and soil productivity (e.g. [75]).

How much of which type of biomass should be retained? Virtually all guidelines advise leaving some standing live or dead trees and downed wood on-site 
Table 9 Minimum harvest residue retention recommended in forest biomass harvesting guidelines, and definitions for coarse woody debris (CWD) when guidelines specifically referred to CWD as a component of harvest residue

\begin{tabular}{|c|c|c|c|c|c|}
\hline \multirow[b]{2}{*}{ Jurisdiction } & \multicolumn{2}{|c|}{ Minimum residue retention ${ }^{a}$} & \multicolumn{2}{|c|}{ Definition of CWD } & \multirow{2}{*}{$\begin{array}{l}\text { CWD notes, position of } \\
\text { diameter measurement }\end{array}$} \\
\hline & All residue $(\%)^{b}$ & Other $\left(h a^{-1}\right)$ & Diameter (cm) & Length (m) & \\
\hline $\mathrm{Pl}$ & & $>200$ pieces CWD & $>7.5$ & $>2$ & \\
\hline $\mathrm{AL}$ & & & $>15.2$ & & \\
\hline IN & $20-33$ & & $>15.2$ & & Large end \\
\hline KY & $15-30$ & & $>7.6$ & $>0.9$ & Small end \\
\hline MA & $25-100$ & & $>7.6$ & $>0.9$ & Small end \\
\hline MD & $20-33$ & & $>7.6-10.2$ & & Large end \\
\hline ME & & & $>10.2$ & & Large end, dead and down \\
\hline $\mathrm{Ml}$ & $17-33$ & & $>15.2$ & & Large end \\
\hline $\mathrm{MN}$ & 33 & & $>15.2$ & & Large end \\
\hline $\mathrm{MO}$ & 33 & & $>15.2$ & & Large end \\
\hline NC & & & $>15.2$ & & Large end \\
\hline PA & $15-30$ & & & & \\
\hline SC & $20-30$ & & $>7.6$ & & Dead and down \\
\hline $\mathrm{VT}$ & $20-33$ & & $>7.6$ & & \\
\hline VA & & & $>10.2$ & & Inside bark \\
\hline WI & 10 & 11 t FWM & $>10.2$ & & Small end, inside bark \\
\hline NE-USA & $25-33$ & & & & \\
\hline PNW-USA ${ }^{d}$ & $30-50$ & & & & \\
\hline PNW-USA & & $10-20 \%$ cover CWD & $>15.2$ & & \\
\hline PNW-USA & & $10-20 \%$ cover CWD & $>7.6$ & $>0.9$ & $\begin{array}{l}\text { Small end, dead and } \\
\text { down }\end{array}$ \\
\hline PNW-USA & & 1-9\% cover deadwood & $>12.7$ & & Dead wood \\
\hline SE-USA & 33 & & & & \\
\hline UK & $50-66^{f}$ & $>20 \mathrm{~m}^{3}$ & $>10$ & $>1$ & \\
\hline SE & 20 & & $>10$ & & \\
\hline $\mathrm{FI}$ & 30 & & $>10$ & & \\
\hline $\mathrm{LT}$ & & $>5 \mathrm{~m}^{3}$ & $>10$ & & \\
\hline Europe $^{h}$ & & & $>10$ & $>2$ & \\
\hline
\end{tabular}

a Some jurisdictions or regions do not quantify retention thresholds, even if retention is recommended

b Proportion of total residue (\%)

c FWM: fine woody material

d FWD only

e Where protection of small mammals and their predators is an objective

$f$ USDA Forest Service definition; an alternate to the definition in the row above

9 For the UK, $66 \%$ of brash or tops from trees $<7-\mathrm{cm} \mathrm{dbh}$

h Minimum diameter is at discretion of individual countries (European Environment Agency, available at https://www.eea.europa.eu/data-and-maps/indicators/ forest-deadwood-1)

when harvesting biomass, although they vary in amount and guidance strength, from "forbidden" to "recommended" (Table 8; Additional file 1: Table ST-5); examples include forbidding the harvest of all standing and lying dead trees greater than $10 \mathrm{~cm}$ in diameter (Finland); and limiting the harvest of standing live and dead trees, and preventing the removal of dead wood lying on the ground that is "older than five years" (Norway). For standing live or dead trees, recommendations for retention include (in decreasing frequency) live but decaying cavity trees or dead snags, residual patches of live trees, mast trees, and den trees (Additional file 1: Table ST-5).

For sites from which harvest residues may be taken, all guidelines suggest retaining some proportion of preexisting standing dead stems, live stems and/or harvest residue when removing forest biomass (Table 8). Approximately $50 \%$ of the guidelines reviewed also contained more precise minimum retention thresholds for woody debris (i.e. CWD (coarse woody debris) and DWM (downed woody material; Table 9), usually as a percentage 
of total non-merchantable material from harvested stems (tops, branches and foliage) that should be left on-site or returned to the site after roadside processing. Retention thresholds based on proportion (\%) of total harvest residue are most commonly used but a few jurisdictions or regions (Wisconsin, Pacific Northwest USA, Lithuania) use different thresholds and units, such as mass or volume per unit area (e.g. tons acre ${ }^{-1}, \mathrm{~m}^{3} \mathrm{ha}^{-1}$ ) or percent cover. Retention thresholds for sites from which biomass can be removed are specified more frequently in North America than in Europe (Additional file 1: Table ST-5), with minimum retention thresholds ranging from $15 \%$ (Kentucky) to 33\% (Missouri) and maximum retention thresholds ranging from 20\% (Minnesota) to 50-66\% (UK). The $11 \mathrm{t} \mathrm{ha}^{-1}$ (5 tons acre ${ }^{-1}$ ) minimum threshold for fine woody debris in Wisconsin is equivalent to $37 \%$ of crown mass in an "average Wisconsin forest", with a range of 25-62\%, depending on the stand (adapted from [76]). Most guidelines suggest leaving additional amounts of harvest residues (Table 9) on sites of poorer quality or greater sensitivity to residue removals, when less downed woody material is present prior to felling, when increasing the intensity of harvesting of merchantable stems, or when reducing rotation length. Increasing the emphasis of forest management on habitat management, reducing forest fire fuel loads, or restoring ecologically degraded sites may affect how much harvest residue should be retained (e.g. Pacific Northwest USA).

Harvest residues can be divided into coarse wood debris (CWD) and fine woody debris (FWD), which is sometimes referred to as fine woody material (FWM) (Table 9). All harvest residues contributes to soil productivity, habitat and soil organic matter and soil $\mathrm{C}$ stocks, although CWD may be more important for habitat than soil properties, at least initially (e.g. [77].), and may decompose and release $\mathrm{CO}_{2}$ and dissolved organic $\mathrm{C}$ more slowly than FWD [78]. FWD often includes nutrient-rich foliage and is important for maintaining site fertility (cf. [25, 79]). Some guidelines define CWD by dimensions: minimum sizes range from $7.5-\mathrm{cm}$ diameter at the small end and $91 \mathrm{~cm}$ in length (Massachusetts), to $15-\mathrm{cm}$ diameter and no specified length (Indiana, Minnesota, Missouri, Pennsylvania); three guidelines (Minnesota, Missouri, Pennsylvania) include stumps as CWD; and some guidelines distinguish CWD from logs (>30-cm diameter; Massachusetts).

Removal or significant disturbance of the forest floor is generally discouraged. Stump or coarse root removal is also discouraged, particularly in North America, but may be used to promote seedling establishment (Maine, Vermont). Some guidelines permit stump removal for energy on certain soils or site types (Finland, UK, Lithuania,
Sweden) or after windthrow which causes uprooting (Denmark).

\section{Water and aquatic ecosystems}

Virtually all biomass harvesting guidelines (or documents referenced by them) note the need to protect water quality, quantity and aquatic ecosystem functions (Table 10; Additional file 1: Table ST-7). Generally, guidelines (and BMPs) for American states advise (i) restricting the amount and timing of harvesting in riparian or streamside zones and wetlands; (ii) minimizing the construction of roads, landings and crossings in wetlands or riparian zones; and (iii) designing roads and landings in upland areas in order to minimize soil damage, maximize the availability of high-quality terrestrial habitat (see General forest management), maintain water quality, flows and temperatures, and reduce the risk of chemical spills into or near water. Nine American states advise restricting forest harvesting activity near vernal or ephemeral ponds, sinkholes, or karst topography to protect special habitats and, to a lesser extent, water quality. State BMPs often advise not leaving harvest residue (tops, branches) in surface water. Most European guidelines advise protecting wetlands, forbidding or restricting harvesting in riparian or streamside areas and lake shores by leaving shelter zones, and minimizing sedimentation to water bodies; buffer widths of undisturbed forest around these features can vary (see also [80]). The UK and Finland specifically advise against leaving harvested biomass adjacent to water bodies (Additional file 1: Table ST-7). The UK guidelines highlight that care is also required to ensure that the siting and handling of roadside harvesting residue piles does not result in material in roadside ditches: leachate from fresh piles can contain high concentrations of nutrients and, together with machine and truck movement, can damage road surfaces and increase erosion and movement of nutrients and sediment to watercourses, especially if ditches are blocked. Also, fresh harvest residue should not be left in trenches created by mounding for restocking on UK sites where there is a high risk of acidification of aquatic systems [67].

\section{Carbon emissions and sequestration}

Carbon is addressed by most (60\%) European but relatively few (24\%) North American guidelines. The breadth and detail of $\mathrm{C}$ discussion vary greatly. UK guidelines are the most in-depth and note that forest harvest residue removal may lead to reduced soil $C$ storage [73] but a "lack of empirical data makes it difficult to predict the impact of stump removal on the exchange of $\mathrm{CO}_{2}$ and other greenhouse gases for different soil types" [81]. Guidelines suggest that the amount of soil $C$ lost will increase with soil $C$ content, which is reinforced by 
Table 10 Water quality, quantity and aquatic ecosystem topics addressed in forest biomass harvesting guidelines, as percent occurrence in 21 North American and 10 European jurisdictions or regions

\begin{tabular}{|c|c|c|}
\hline Indicator, consequence or action ${ }^{a}$ & North America & Europe \\
\hline Water quality [any action or consequence) & 90 & 50 \\
\hline \multicolumn{3}{|l|}{ Actions to prevent or minimize sedimentation } \\
\hline Minimize stream crossings & 81 & 20 \\
\hline Avoid exposing mineral soil & 81 & 20 \\
\hline Design roads, landings to minimize runoff directly to water bodies & 90 & 30 \\
\hline Use appropriate harvesting equipment & 76 & 10 \\
\hline Harvest when soil frozen or dry & 62 & 30 \\
\hline \multicolumn{3}{|l|}{ Consequence } \\
\hline Sedimentation & 76 & 30 \\
\hline \multicolumn{3}{|l|}{ Actions to prevent or minimize leaching/contamination ${ }^{b}$} \\
\hline Avoid leaving residue in or near water & 76 & 50 \\
\hline Minimize potential for chemical spills & 76 & 30 \\
\hline \multicolumn{3}{|l|}{ Consequence } \\
\hline Leaching/contamination ${ }^{b}$ & 86 & 60 \\
\hline \multicolumn{3}{|l|}{ Water quantity/flow } \\
\hline Maintain desired water flow and drainage & 81 & 20 \\
\hline \multicolumn{3}{|l|}{ Aquatic ecosystem } \\
\hline \multicolumn{3}{|l|}{ Indicator } \\
\hline Water temperature/shading & 76 & 10 \\
\hline \multicolumn{3}{|l|}{ Actions } \\
\hline Leave live trees, dead standing trees, CWD, buffers, RMZ, SMZ & 95 & 70 \\
\hline Protect wetlands & 100 & 60 \\
\hline Protect karst pools or vernal pools & 62 & 0 \\
\hline
\end{tabular}

a See Additional file 1: Table ST-7 for more detail

b See also Tables 4 and 5 for identification and protection of sensitive sites and soils $R M Z$ riparian management zone, $S M Z$ stream management zone

stump harvesting trial results [82, 83]. More recent UK guidelines $[34,67]$ recommend biomass retention to minimize $C$ loss from sites, and this is consistent with guidance for maintaining soil productivity (e.g. do not deplete site fertility) and biodiversity (e.g. leave some standing and fallen deadwood) on most but not all sites [84]). In addition to conserving $\mathrm{C}$ on-site through residue retention, UK guidelines also recommend minimizing the $\mathrm{C}$ footprint of forestry operations (e.g. minimizing vehicle fuel consumption) and planning future forests in the context of climate change.

Other guidelines touch on forest C cycling and GHG emissions in general terms, noting that forests sequester $\mathrm{C}$ as they grow (Michigan, Missouri, Vermont, Southeast USA, Italy, Austria), that this is desirable (Norway), and that use of bioenergy and bioproducts based on forest biomass reduce $\mathrm{C}$ emissions (Alabama, Indiana) compared to fossil fuels and materials made from fossil fuels, with Pennsylvania providing a detailed policy rationale for bioenergy based on $\mathrm{C}$ cycling. Finland's guidelines stress the importance of replacing fossil fuels with renewable energy, such as bioenergy from forest harvest residues.

Some guidelines address $\mathrm{C}$ accounting and life-cycle analysis (LCA) of $\mathrm{C}$ emissions: those for the Northeast USA note the need for LCA of forest biomass use and C emissions and list recommendations for $\mathrm{C}$ accounting, much of it at a site level. Similarly, GHG accounting for bioenergy is recommended in supporting documentation for Vermont guidelines [85] and is a mandatory requirement for receiving bioenergy credits in Massachusetts. Finland (guidelines) and Lithuania (supporting documents) refer to country-level forest $C$ accounting, while guidelines for Pacific Northwest and Southeast USA are clear that $\mathrm{C}$ accounting is beyond their scope, while addressing $\mathrm{C}$ at a site level is not.

\section{Social values}

Forests meet intangible societal needs, in addition to the tangible economic benefits provided by biomass harvesting (which are not addressed in guidelines and thus not considered). Forest biomass harvesting can affect human 
Table 11 Social and cultural values topics addressed in forest biomass harvesting guidelines, as percent occurrence in 21 North American and 10 European jurisdictions or regions

\begin{tabular}{lll}
\hline Value or concern $^{\text {a }}$ & $\begin{array}{l}\text { North } \\
\text { America }\end{array}$ & Europe \\
\hline Aesthetics and recreation (any value or concern) & 33 & 60 \\
Aesthetic, visual or landscape quality, c $^{\text {, c }}$ & 33 & 40 \\
Recreation (including right-of-way and access) & 10 & 40 \\
Noise & 5 & 0 \\
Other (undefined social concerns) & 5 & 0 \\
& 0 & 0 \\
Archaeology, history, culture ${ }^{d}$ (any value or concern) & 10 & 60 \\
Archaeological and historical sites ${ }^{\text {eff }}$ & 10 & 40 \\
Sites of cultural and/or social importance, $^{\text {ef }}$ & 10 & 50 \\
\hline
\end{tabular}

a See Additional file 1: Table ST-8 for more detail

${ }^{b}$ MI (2012)

c UK (1997)

d Meaning of "cultural" is not always clear and could sometimes refer to historical sites

e MI (2010) biomass harvesting guidelines refer users to other guidelines for social values

${ }^{f}$ UK (2017) Forestry Standards

activities that take place within forests and the resultant sense of place that nurtures culture, history and wellbeing. These social values and activities include aesthetics and recreation, and biomass harvesting guidelines typically recommend management activities that will maintain or enhances visual quality [86], hiking and ski trails, rights-of-way, and access across harvested sites. Guidelines most often address visual quality (60\% of European and 33\% of North American guidelines); there are fewer recommendations for protecting recreation in Europe (40\% of guidelines) and fewer again in North American (10\% of guidelines) (Table 11) although, as for other guideline topics, we did not search general SFM guidelines unless directed to by biomass harvesting guidelines. Forest sites can also be culturally important, especially for indigenous peoples, and it is often recommended that these sites and those with cultural, historical and archaeological remains be avoided or protected during forestry operations; as with aesthetics and recreation, recommendations are more prevalent in Europe than North America (60 and $10 \%$ of guidelines, respectively). Hunting and foraging for non-forest timber products (such as berries and mushrooms) can have both recreational and economic values. Provision of patches of trees for shelter for game animals is mentioned in Finnish biomass guidance related to uneven-aged management; and Norwegian guidelines note that the public has right-of-access to forests to pick berries and mushrooms, as in several other northern European jurisdictions.

\section{Discussion}

\section{Overview and context for forest biomass harvesting guidelines}

We found guidelines addressing ecologically sustainable harvest of forest residues for 32 different jurisdictions or regions. In addition, some European countries (e.g. Belgium, Hungary, Poland) restrict or otherwise discourage harvesting of forest biomass in some stands or sites, or restrict the use of specific tree parts (e.g. stumps, maximum diameter of pieces) that would be eligible for credit as renewable energy sources [26]. Many jurisdictions have comprehensive forest management regulations, best management practices or guidelines that do not specifically address forest biomass harvesting, such as New Zealand, Ireland, most Canadian provinces [87], and individual states in Australia [38] and the USA [88]. Some North American jurisdictions considered whether or not forest biomass-specific guidelines were needed and then chose not to proceed with their development, including Ontario [89, 90], Nova Scotia [91], California [92, 93], Oregon [94], North Carolina [39] and Washington [95]. In some instances, either current SFM and related environmental regulations (e.g. Ontario [90]) or forest biomass-related amendments to existing forest practices rules (e.g. Washington [96]) were considered sufficient. It is also possible that some jurisdictions lack guidelines because biomass harvesting or full-tree logging does not take place.

The guidelines that we reviewed broadly cover the same topics and often make similar general recommendations. To protect biodiversity, for example, most guidelines advise restricting biomass harvesting near critical habitats and retaining appropriate vegetation and dead wood for habitat. To protect sensitive soils, most guidelines advise restricting biomass removal on sites identified as sensitive; site sensitivity is often based on a combination of indicators such as slope, soil depth, and soil moisture regime, all of which may be related to susceptibility to erosion, compaction, loss of fertility and resilience to harvesting. To protect water quality, most guidelines advise retaining vegetative buffers and restricting harvesting and associated infrastructure around surface and groundwater (e.g. karst) features.

The emphasis on specific topics differs. European guidelines provide more detail on compensatory ash and fertilizer application and on utilization of stumps, perhaps because of a longer history and greater intensity of forest use and a more obvious need to address nutrient deficiencies resulting from forest biomass harvesting. Guidelines in the USA typically provide more detailed recommendations regarding habitat characteristics (e.g. mast and den trees). It is possible that these differences reflects different management or societal concerns, or 
that they are addressed in higher-level guidelines or regulations that we did not review (e.g. Finland, Sweden).

The need for guidance specific to forest biomass harvesting, set within general SFM governance, will likely grow as governments increasingly enact energy policies to mitigate climate change and as forest biomass harvesting and conversion technologies become more efficient [42-45] and profitable. Increased European demand for both domestic- and foreign-sourced wood pellets [97] and adoption of the cascading principle in national forest policies [26] (i.e. increasing the importance of woody residues, compared to roundwood, as a source of pellets) will likely increase demand for forest harvest residues. In the case of pellets in the USA, the land base from which forest biomass is potentially available at the landscape scale is constrained by competing demands for land for non-forest uses, although increased demand for pellets may reduce pressures to convert forest land in the Southeast USA [98, 99]. Even now, operationally harvested sites sometimes leave less harvesting residue [46] than is recommended in any of the 17 guidelines with stated thresholds (Table 10), and this may occur more frequently as demand for forest biomass increases.

\section{Designing forest biomass harvesting guidelines General principles and context}

The purpose of forest biomass harvesting guidelines is to facilitate the economical harvesting of biomass while maintaining environmental and social sustainability. If guidelines are needed ("why"), then they should be appropriately comprehensive ("what") and aid end-users ("who") to apply operations appropriately ("how") in complying with SFM principles and relevant regulations within their jurisdiction. A consultative and collaborative process with stakeholders (e.g. [100]) which identifies and defines the objectives, scope, scientific rationale and desired outcomes will help ensure that guidelines are effective.

When developing biomass harvesting guidelines, "as simple as possible but as complex as necessary" and " $[\mathrm{s}]$ ince guidance is not binding, whether or not it really is useful will depend on its intrinsic merit" [101] are useful rules-of-thumb because guidelines must be realistic enough to be applied while addressing complex and potentially conflicting needs. Objectives and appropriate temporal and spatial scales of concern may vary, depending on the nature of the issue and the potential user (e.g. variation in forest landscapes [47]). Guidelines must be based on sound science, but should acknowledge the difficulty of making unambiguous general recommendations based on research results from specific sites [32, 48, 102], or a paucity of monitoring data across a range of sites (cf. $[103,104])$. While addressing jurisdiction-specific issues, broad consistency in approaches across jurisdictions (including scientific rationale and evidence of implementation) may help ensure that forest biomass can be traded globally without barriers because of agreement on what is required for biomass to be considered sustainably sourced [32].

Comparisons with jurisdictions or regions with similar forest types and research on current harvesting impacts can be instructive. Guideline developers in Maine took into account that fine woody debris retention during operational whole-tree harvesting already exceeded threshold amounts in guidelines of nearby states [105], partly because of harvest inefficiency and partly because of compliance with existing BMPs for harvest residue retention to reduce erosion on skid trails); however, coarse woody debris retention was less than recommended in other guidelines, possibly because of the legacy of historical harvesting practices. Retention levels of downed woody debris in North Carolina were least when thresholds were not specified and were left to logger (i.e. feller) discretion; however, even these levels exceeded Forest Guild recommendations, either because of harvesting inefficiency or non-merchantability of forest biomass [106]. Existing recommendations may have been adequate for forest biomass retention in both Maine and North Carolina, but this could change in the future if biomass prices increase and harvesting becomes more efficient.

\section{Underlying science and operational experience}

Guidelines should be based on relevant science (e.g. [48]). Forest biomass removals have the potential to reduce forest productivity (e.g. Nordic countries [25, 107]), but not always (e.g. North America [108]), and can negatively affect biodiversity $[25,79]$. However, most research is site-specific or relatively short-term and cannot necessarily predict how harvesting affects productivity or biodiversity on operational scales, or elsewhere [32], or over the long-term. Furthermore, scale matters: the vulnerability of species to forest biomass harvesting may vary with both the intensity of harvesting on specific sites and the amount of land subjected to more intensive harvesting [109], although some spatial biodiversity issues can be addressed by leaving intact corridors [110] or building residue windrows [111] between undisturbed ecosystems. Given the challenge of applying limited sitespecific experimental results across sometimes complex landscapes, end-users may perceive scientific knowledge as ambiguous and conflicting, and reasons to modify current SFM practices by developing biomass harvesting guidelines may be unclear and unconvincing, especially if costs are expected to increase with implementation [39]. Modelling approaches may overcome some weaknesses 
in short-term empirical field study data, but require a sound conceptual framework, and validation under relevant conditions using appropriate empirical data; in the absence of such data, reliance on local expertise may be needed [32].

Guideline recommendations are subject to uncertainty [112] and relevance can change over time: updates of the guidelines may then be warranted. Voluntary guidelines may be easier to update than laws or certification standards. Guideline development should be embedded in an adaptive management framework (e.g. [103, 104], that is collaborative [113] and uses monitoring to ensure compliance (successful application), effectiveness (meeting objectives) and validation (research to understand treatment response [114]. Twin-plot designs [115, 116] adapted for simple biomass removal trials [117] can also help generate statistically valid results from a wide range of sites. However, regardless of objective, monitoring can be limited by cost.

Distilling useable recommendations from available science and combining this with local operational experience requires that guidelines define key terms; articulate information gaps, uncertainties and value-based priorities; and provide guidance appropriate to the level of scientific understanding. In the guidelines we reviewed, definitions and the specificity of guidance varied, and information gaps were not always identified; for example, US harvesting guidelines use a variety of names to describe natural communities that are significant because they are unusual or of biological importance, such as "sensitive areas", "sensitive natural communities", "sensitive habitats", "high-quality natural communities" and "high conservation value forests". Most guidelines give examples of key communities to be preserved and provide links to supporting information, typically a natural features database relevant to the jurisdiction or region. These US state databases typically apply a standard classification and terminology for conservation status (e.g. [118]). This consistency facilitates common understanding, clear communication, and an ability to compare guidelines and the results of their application.

Site-level retention thresholds for post-harvest residues range from about $15 \%$ to $50 \%$ of non-merchantable material. Landscape-level retention will inevitably be greater when sites from which no residue can be taken are included. In Sweden, it is estimated that $40 \%$ of final fellings are on sites where all residue should be retained, giving a national site-level retention average of $28 \%$ of total residues (excluding stumps) [19]. Site-level thresholds may be based on local nutrient budget research in some jurisdictions or regions (e.g. New Brunswick, Minnesota, France, Netherlands, Sweden, Finland), but the rationale for retention thresholds in other guidelines is less clear. Normal amounts of breakage during conventional stem harvest met retention thresholds on most sites in Minnesota and Wisconsin; and guidelines for the Northeast USA suggest using existing amounts of naturally occurring downed wood as a guide for retention. Normal breakage during stem harvesting may become an inappropriate standard if harvesting technology becomes more efficient. Standards based on naturally occurring downed wood may be inappropriate if forests have been heavily thinned, or if sites have been repeatedly clearcut over successive rotations $[43,105,119]$, or if amounts prior to settlement or industrial use are unknown. Future climate change impacts add another layer of uncertainty in setting standards.

Stumps are a potential source of biomass feedstock, are extracted for insect and root disease control (e.g. [120]), and have been used intermittently for pulp fibre and/or bioenergy production since the early 1970s [121]. Amounts removed are small compared to harvest residues. For example, annual areas stumped as a proportion of area clearcut are $<10 \%$ in Finland (and decreasing largely because of environmental concerns (e.g. [122]); $\approx 1 \%$ in Sweden $(\approx 2000$ ha, derived from $[19,123]$ cf. limited to 2500 ha $\mathrm{y}^{-1}$ from certified forests [124]); and $<0.25 \%$ in B.C. for root rot control $[125,126]$. The environmental impacts of stump lifting or harvesting has been well researched and reviewed [120, 127-131] and specific stumping guidelines for bioenergy have been developed in Sweden, Finland, Lithuania and the UK $[126,132]$. Guidance for stump uprooting to control root rot has also been produced in British Columbia [133], where up-rooted stumps are currently left on-site; revision to provide guidance for their removal and use as bioenergy feedstock may be possible [126].

We did not review specific stumping guidelines because our focus was on biomass harvesting guidelines, most of which forbid stump removal for bioenergy. But is it prudent to prohibit a practice per se rather than address and minimize its ecological impacts? A recent review [131] concludes that "stump harvesting for bioenergy is a possible and acceptable" practice because the degree of the biggest impact (i.e. on species requiring dead wood) can be mitigated by leaving an appropriate number of stumps at landscape scales. Additionally, excavator-mounted tube-saws developed in both Nordic countries and the USA can cut lateral roots so that stump cores can be removed with minimal soil disturbance $[126,134]$ : roots can account for over $70 \%$ of stump biomass in spruce and it is root removal that causes most of the soil disturbance [135]. Focusing on environmental impacts during guideline development rather than prohibiting stump removal at the outset may allow future access to a currently 
little-used feedstock source [126] but only if removals are shown to be environmentally acceptable.

Guidance for soil conservation varies considerably across jurisdictions. Many guidelines suggest that forest biomass harvesting can decrease productivity in relatively unproductive soils, including those that are (i) "dry" or "wet" and "nutrient-poor"; (ii) "acidic" or "acidprone", and (iii) "coarse-textured", "sandy", or "organic". These qualitative terms are often undefined; alternatively, some guidelines use terminology based on standardized soil classification systems (e.g. the UK, or those developed by the USDA Natural Resource Conservation Service). Some provide quantitative and standard indicators of soil moisture or fertility, but threshold levels may be given in units that are not directly comparable with other guidelines (e.g. total available water-holding capacity in soil without specifying soil depth). Two (New Brunswick, the Netherlands) use nutrient budget models to predict residue removal effects on fertility. When individual indicators are used, presence or threshold exceedance by one indicator can categorize a soil as "sensitive", regardless of the others. Single indicators may be more prone to oversimplified application than integrated indicators, while soil classification systems integrate several indicators. Forest ecosystem classification systems (e.g. Finland), typically integrate soil, vegetation, site and climate factors, and have the broadest application to a range of environmental values besides soils.

Impacts of forest biomass harvesting on different soil types are difficult to predict because underlying mechanisms are not always well-understood, and hence guidelines will always represent a balance between general and specific recommendations (e.g. [42]). Guidance for protecting soils that seems general may indicate that effects of forest biomass removal are either not studied or have been insufficiently studied to address all situations with certainty, as noted in Minnesota's guidelines. We recommend that guidelines be as precise as possible in defining sensitive soils and sites (including thresholds for quantitative indicators); use accepted, well-defined and standard vocabulary; and explicitly indicate knowledge gaps and avoid precision that is not justified. Links to detailed background information can be helpful (e.g. soil information accessible through the USDA Natural Resources Conservation Service portal [136]), as can graphic summaries (UK) or pictures of sensitive soils and sites (e.g. Wisconsin [137]) and of desirable and undesirable outcomes [42]. Guidelines should provide links to supporting information, wherever possible.

Most guidelines do not address how to minimize $\mathrm{C}$ emissions and maximize $C$ sequestration when harvesting forest biomass-but should they? If so, what is needed? Carbon accounting using life-cycle assessment
(LCA) or life-cycle approaches ("cradle to grave") can be contentious for forest bioenergy at a landscape level or above [13, 18, 138-143] when assessments use different assumptions (e.g. "C neutrality" of biomass combustion $[138,144,145])$. However, biomass harvesting guidelines are typically applied at a site level, where the impact of harvest residue removal on atmospheric $\mathrm{C}$ is negligible compared to bioenergy benefits [146], and higher-level "C neutrality" debates may seem abstract and of less of obvious importance to operators and managers than biomass removal impacts on soil, water, biodiversity and social values. Notwithstanding these issues, guidelines can still address $C$ management and potentially minimize net $\mathrm{C}$ emissions by encouraging (i) the use of harvest residues which might otherwise be burned on-site or at roadside (as in much of Canada) or rapidly decompose (e.g. small-diameter fine woody debris); (ii) use of stems from forests with high mortality or high risk of disturbance [147]; (iii) removal of harvest residues in preference to live stems for energy production; (iv) use of suppressed live trees in preference to crop tree stems [148] because long-lived solid wood products from crop trees are more valuable and sequester $C$ off-site in harvested wood products [149-151]; and (v) prevention of land-use conversion [152].

At a site level, effects of forest biomass harvesting on $\mathrm{C}$ emissions are uncertain [141], and practices intended to minimize $\mathrm{C}$ emissions (e.g. amounts and types of biomass retained cf. [78]) may help forest managers meet other SFM objectives, but may also conflict with them (e.g. emphasis on removal of fine rather than coarse residues may reduce soil nutrient availability or, conversely, removal of coarse rather than fine residues may reduce important habitat that supports biodiversity). Metaanalyses indicate that harvest residue removal can cause a decrease in soil $C[153,154]$, but response can vary with soil order [155]. Some individual studies show no effect of residue removal [153]; however, residue removal on organo-mineral soils in the UK made conditions less favourable for decomposers and led to unexpected increases in soil C stocks over 28 years [84], as also found in a global meta-analysis [156]. (See also recent reviews in [157] and [158].) Clearly, care must be taken when applying scientific knowledge generated at a site-level to a wider range of site types.

New and updated biomass harvesting guidelines should address site-level $\mathrm{C}$ management, but further research is needed to document how different harvesting scenarios affect net $C$ sequestration (including residue removal impacts on soil fertility and resultant tree growth) and how increased $C$ sequestration is compatible with other objectives. Pending such research, guidance on $\mathrm{C}$ should remain relatively simple and practical 
$[16,48]$, and focus on site-level objectives that are tangible for landowners and operators. Guidelines should emphasize that $\mathrm{C}$ management is important and biomass retention levels that benefit environmental values also typically increase on-site $C$ stocks (but not always $[84,156])$. Finally, guideline developers should note that it is now common for both regulatory and market-driven systems to consider the impacts of forest management emissions; for example, the European Union (EU) Renewable Energy Directive [159], to be implemented in 2021, requires that member countries managing forest biomass for energy have strategies to conserve or enhance forest $C$ stocks and sinks. Including $\mathrm{C}$ conservation and sequestration recommendations in guidelines will likely become important in the near future.

Social values (excluding economics) are addressed more frequently by European than by North American guidelines (Table 11). Their consideration may become increasingly important but there is little research literature, especially for North America, on the effects of harvest residue removal on social values, including non-timber forest products [79]. One review found that residue and stump removal are generally not a threat to native berry species and fish and, in the absence of direct studies, deduced that residue retention may be helpful as browse but impede reindeer access to underlying lichens [79].

Aesthetics, including visual quality, are hard to quantify and translate into policy at anything other than a superficial level [160]. Harvest residue retention can have a negative (but temporary) impact on aesthetics [161-163]. However, there are trade-offs; for example, residue retention can help prevent soil rutting, which can have a strong negative impact on aesthetics and on recreational use by impeding movement across sites ([164] in [165]). In Fennoscandia, visual quality was also associated with the type and intensity of biomass harvesting [86]. Whole-tree thinning was appealing because it increased stand openness; but stumping had a negative impact on "landscape appreciation immediately after extraction", although this declined over time as vegetation regrew $[79,86]$. Aesthetic impacts can be reduced through appropriate guidance on harvest residue extraction, but public perceptions of the appearance of dead and downed wood in natural boreal forests can improve if the public are provided with more information on its ecological role [166], suggesting that explanatory text may be appropriate in guidelines.

Increasing rotation length is an option for protecting soil, water and biodiversity (Table 8, Additional file 1: Table ST-5). It may also increase protection of cultural heritage sites from damage resulting from equipment traffic and scarification [79, 167] and extend berry and mushroom production for some species and benefit shrub forage for ungulates, although it may increase the time between opportunities for browsing of early-succession trees [167]. Trade-offs between objectives, the management practices applied to achieve them, and resultant impacts on other objectives will inevitably depend on the local context for social, economic and ecological values; on the range of stakeholders involved; and on the decision-making processes used.

\section{Facilitating adoption of guidelines by end-users}

Biomass harvesting guidelines are typically voluntary; to be effective, they must be adopted and applied by the target audience, and thus developers must understand the motivations and concerns of end-users. For public forest lands, governments can set policies, regulations and guidance to meet societal expectations and demands that may be greater than for private land; users can also be those responsible for enforcement of standards and regulations. However, much of the forest land likely to supply biomass, particularly in the USA and Europe, is privately owned and guideline users are likely to be non-industrial private or corporate forest landowners, professional foresters and loggers. Additionally, guidelines may encourage acceptance of sustainable forest biomass harvesting practices by the broader public, although this is not their primary objective.

Preferences for voluntary or mandated practices can vary with users: forest managers, landowners and loggers in the Southeast USA all favoured voluntary over mandated biomass harvesting guidelines $[39,168]$, but loggers in North Carolina were more amenable than landowners to mandated practices [39]. Which is more effective is unclear, although implementation rates of BMPs (similar to guidelines) for water quality did not differ between states with voluntary and states with mandatory BMPs [169]. New or innovative voluntary practices are more likely to be adopted when landowners perceive that the new practices $(i)$ help them achieve their personal goals, (ii) are preferable to the older or alternative practice, and (iii) are easy to test and evaluate [170]. Clearly, a need must be demonstrated and the benefits of adopting guidelines must be apparent to the end-user [39, 101]. This can be difficult because, as with other conservationoriented practices, the problems and benefits may not be obvious and the time between treatment and response (e.g. soil productivity) may be long [170]. This highlights the need to clearly identify end-users and emphasize the information that is most relevant to them and consistent with their values and goals. New practices are not adopted simply because stakeholders lack information: the decision to invest time and resources in adopting 
new practices is made in the context of individual values (including economics) and other sometimes-conflicting priorities [170].

Values important to private forest landowners vary [171-176] and may affect landowners' interest in biomass harvesting and in implementing guidelines for this $[168,175,177,178]$. We do not know how guideline users might perceive the relative importance of different environmental SFM criteria in guidelines and how this might vary with region and even terminology; for example, "enhancing wildlife habitat" may be perceived differently than "protecting biodiversity", and C may not be considered as important as other criteria if the direct benefits and impacts of $\mathrm{C}$ management are not apparent (see General principles and context).

How much information to include in guidelines and how best to present it depends on the end-users. For example, emphasizing different harvesting techniques and their (potentially multiple) benefits, along with a decision key ("how"), may be more appropriate for operators but emphasizing SFM criteria ("where", "why") may be more useful for planning foresters. Employing a variety of tools (site visits, on-line tutorials, etc.) can also encourage the adoption of desired practices and improve the implementation of biomass harvesting guidelines (e.g. [179]).

\section{Assessment and updating of guidelines}

Once developed and implemented, the effectiveness of biomass harvesting guidelines must be monitored and guidelines reviewed and updated to ensure that they remain effective and incorporate new and relevant scientific knowledge, typically via adaptive management (see Underlying science and operational experience). The intent to update periodically, whether at fixed intervals or pending new information, is explicitly stated in six North American and at least two European guidelines. To date, five guidelines (Minnesota, Wisconsin, Finland, Sweden, UK) and one related PEFC standard (Norway) have been revised at least once (on average every seven years), one was re-edited (Massachusetts), and one jurisdiction (Michigan) produced stand retention guidance for all harvesting that contained information relevant to earlier biomass guidance. Many other guidelines are relatively new and updating may not yet be warranted. Limited funding may also prevent assessment of guideline effectiveness, as with forestry BMPs in the US [88].

The experience gained in monitoring and updating US state forestry BMPs for protecting water quality is instructive for revising biomass harvesting guidelines because they contain similar elements (e.g. Table 10), and the implementation rate of BMPs is periodically assessed. BMPs arose from federal legislation (1987 Clean Water
Act) that addressed water pollution from non-point sources, including forestry, but are developed at the state level. General BMPs for forestry for the US have been published [180] and all 50 states have state-specific forestry BMPs, with varying degrees of monitoring of their implementation [88]. Implementation rates are high, have improved over time, and have minimized impacts of harvesting on water quality and aquatic ecosystems [169, 181, 182], even though the level of detail in BMPs and the extent to which practices are voluntary or mandated vary $[169,183]$. Improved outcomes were achieved through better pre-harvest planning, use of professional foresters, improved landowner awareness, and logger training [169], especially when the latter was supported by thirdparty certification requirements [182]. Implementation of BMPs for water quality also improved slightly in Georgia when the Sustainable Forestry Initiative (SFI) Fiber Sourcing Standard was met [184]. Generalized guidance complicates assessment and enforcement of BMP compliance [185]; nonetheless, BMP evaluation and improvement processes for maintaining water quality may provide a useful framework for updating and improving biomass harvesting guidelines.

On the other hand, guideline effectiveness may depend more on good implementation than on guideline revisions. For example, forest harvesting operations with biomass recovery in Virginia had lower compliance with BMPs for water quality than conventional harvesting operations (i.e. implementation), specifically in stream management zones [186], but overall erosion rates (i.e. effectiveness) did not differ between biomass and conventional harvest areas [187]. The authors concluded that satisfactory compliance would be achieved through better implementation of existing BMPs than creation of additional BMPs per se.

\section{Summary of recommendations for guideline development and revisions}

We have summarized topics for developers of forest biomass harvesting guidelines to consider, based on this and previous reviews (Table 12; Additional file 2: Tables ST-10 and ST-11). These topics are categorized by rationale ("why"), scope ("what"), process and principles, guideline components and format ("how"), and whether future updating is expected. In addition to considerations suggested previously by other reviews, we stress (i) the importance of well-defined and understood terminology, consistent where possible with guidelines in other jurisdictions or regions; (ii) guidance based on relevant research and current knowledge, without applying knowledge more broadly than warranted by the data; (iii) use of indicators of sensitive soils, sites, and stands which relate to ecological 
Table 12 Summary of recommendations from reviews of forest biomass harvesting guidelines (see detailed recommendations and their sources in Additional file 2: Tables ST-10 and ST-11)

\begin{tabular}{|c|c|c|}
\hline Topic & Suggested actions & Examples \\
\hline \multirow[t]{13}{*}{ Rationale (Why?) } & Articulate the need for unique guidelines & $\begin{array}{l}\text { a. Produce environmentally and socially sustainable forest } \\
\text { biomass feedstock for the bioeconomy }\end{array}$ \\
\hline & \multirow{6}{*}{$\begin{array}{l}\text { Identify benefits of management for forest biomass to } \\
\text { forest landowners, forestry and society }\end{array}$} & a. Reduced risks from damaging agents \\
\hline & & b. Reduced costs of site preparation \\
\hline & & c. Incentive to maintain land in forestry \\
\hline & & d. Increase ecologically based management of forests \\
\hline & & e. Additional income stream \\
\hline & & f. Recover energy and decrease fossil C emissions \\
\hline & \multirow{3}{*}{$\begin{array}{l}\text { Identify benefits of comprehensive guidelines on public } \\
\text { and market perception }\end{array}$} & a. Build public confidence in biomass harvesting \\
\hline & & b. Proactive and provides opportunity for voluntary action \\
\hline & & c. Demonstrate commitment to sustainability \\
\hline & \multirow[t]{3}{*}{ Anticipate changing global policy issues } & $\begin{array}{l}\text { a. Access to international markets (importation standards, } \\
\text { regulations) }\end{array}$ \\
\hline & & b. Third-party, market-driven certification \\
\hline & & c. How impacts are evaluated (e.g. life-cycle analysis) \\
\hline \multirow[t]{7}{*}{ Scope (Who, what, where?) } & \multirow[t]{4}{*}{ Define breadth of guidelines } & a. Land ownership \\
\hline & & b. User groups \\
\hline & & $\begin{array}{l}\text { c. Type of biomass (e.g. tree tops and branches only, } \\
\text { stumps, purpose-grown SRIC plantations) }\end{array}$ \\
\hline & & d. Ecosystem and cultural components to protect \\
\hline & Define guideline relationship to existing policy & General SFM guidelines, BMPs, and regulations \\
\hline & Decide if voluntary or mandatory & \\
\hline & $\begin{array}{l}\text { Ensure guideline jurisdiction is appropriate for imple- } \\
\text { menting, monitoring, enforcement, updating }\end{array}$ & \\
\hline \multirow[t]{8}{*}{ Development (How?) } & $\begin{array}{l}\text { Begin consulting with broad range of stakeholders early } \\
\text { in guideline development }\end{array}$ & $\begin{array}{l}\text { Forest managers, operators, landowners, eNGOs, Indig- } \\
\text { enous peoples, public }\end{array}$ \\
\hline & $\begin{array}{l}\text { Consolidate information from existing SFM manuals for } \\
\text { jurisdiction }\end{array}$ & \\
\hline & Base guidelines on appropriate scientific research & \\
\hline & $\begin{array}{l}\text { Acknowledge uncertainties and gaps in knowledge and } \\
\text { formulate recommendations accordingly }\end{array}$ & \\
\hline & $\begin{array}{l}\text { Interpret knowledge within context of local ecosystems } \\
\text { and experience }\end{array}$ & \\
\hline & $\begin{array}{l}\text { Refer to guidelines from other jurisdictions, but not } \\
\text { uncritically }\end{array}$ & \\
\hline & Use peer-review process during guideline development & \\
\hline & $\begin{array}{l}\text { Make guidelines clear, practical and flexible, allowing for } \\
\text { professional judgement when required }\end{array}$ & \\
\hline \multirow[t]{10}{*}{ Components } & Consider how to organize information & $\begin{array}{l}\text { For manuals, use sidebars, indices, references for ancillary } \\
\text { information and links to regulations }\end{array}$ \\
\hline & Consider different emphases, depending on user & $\begin{array}{l}\text { Emphasize "how" for operator vs. "where" and "why" for } \\
\text { forest managers, planners, etc., vs. "why" for public }\end{array}$ \\
\hline & \multirow[t]{3}{*}{ Define all important terms } & a. Biomass-related terms, e.g. CWD \\
\hline & & b. Sensitive ecosystems \\
\hline & & c. Soil characteristics, e.g. "erodible" \\
\hline & \multirow[t]{4}{*}{ Articulate the benefits of retaining some dead wood } & a. Habitat \\
\hline & & b. Soil quality, minimizing erosion and runoff \\
\hline & & c. C sequestration \\
\hline & & d. Fuel management \\
\hline & $\begin{array}{l}\text { Clarify how to identify soils and/or sites sensitive to } \\
\text { intensified biomass removal }\end{array}$ & $\begin{array}{l}\text { Define key characteristics, use of integrated field-based } \\
\text { site tools, use of soil series and mapping, modelling, etc. }\end{array}$ \\
\hline
\end{tabular}


Table 12 (continued)

\begin{tabular}{|c|c|c|}
\hline Topic & Suggested actions & Examples \\
\hline & Set appropriate retention levels for biomass and sites; be & a. Amounts \\
\hline & clear how values were determined & b. Types \\
\hline & & c. Distribution \\
\hline & Provide operational guidance in retaining biomass & \\
\hline Format & Paper manual vs. digital manual & \\
\hline \multirow[t]{2}{*}{ Extension, Continuing education } & Use in-person meetings and digital media for extension & a. Field tours, workshops \\
\hline & & $\begin{array}{l}\text { b. Webinars, YouTube videos, etc., especially for specific } \\
\text { operational issues }\end{array}$ \\
\hline \multirow[t]{3}{*}{ Updating } & $\begin{array}{l}\text { Monitor and update through adaptive management } \\
\text { approaches }\end{array}$ & $\begin{array}{l}\text { a. Systematic surveys for implementation and for effec- } \\
\text { tiveness (e.g. as for BMP evaluations) }\end{array}$ \\
\hline & & $\begin{array}{l}\text { b. Small-scale operational research ("twin-plot" approach, } \\
\text { etc.) }\end{array}$ \\
\hline & & c. Update review of scientific literature \\
\hline
\end{tabular}

processes and can be applied operationally; (iv) and incorporation of $\mathrm{C}$ balance considerations when defining forest biomass availability, including temporal considerations of the forestry and of the bioenergy/bioproducts counterfactual (i.e. the fate of forest $\mathrm{C}$ if biomass is not harvested and bioenergy or bioproducts are not produced) and impacts on long-term storage of $\mathrm{C}$ in the soil.

We agree with authors who have concluded that guideline effectiveness depends as much on the process of their development as on their specific recommendations [31], a principle long understood in planning [188] and natural resources management extension work (e.g. [179]). It is important to know and understand the needs of potential end-users and to begin meaningful consultation with a broad range of stakeholders early in the guideline development process. As noted earlier, the needs of end-users will determine how much information to include in guidelines, how to best organize and present the information, and in what formats. Involvement of end-users at all stages is important to ensure effective implementation and can be aided using a variety of communication approaches and platforms, including those that foster continuing education.

Finally, long-term effectiveness of biomass harvesting guidelines requires a commitment to monitoring outcomes in the field, to scientific and operational research to answer questions which arise, and to dissemination of research results and their incorporation into revised guidelines within an AAM framework of "do-evaluate-refine".

\section{Conclusion}

Rapid deployment of renewable energy is increasingly needed to help mitigate what some news media and governments are now formally and explicitly calling a "climate crisis" or "climate change emergency" (e.g. [189-192]). This urgency may greatly increase demand for forest harvest residue as feedstock for bioenergy and bioproducts. If so, then biomass harvesting guidelines, as part of broader sustainable forest management practices, should help alleviate public concerns about protecting environmental and social values [193], build trust [194] in forest management and governance processes [195, 196] and help forest managers meet marketplace standards for sustainability. While global trade in sustainable commodities is typically governed through certification schemes or importation criteria [197-199], guidelines help ensure that these higher-level standards are measurable and acceptable, and that global trade is fair.

Some level of consistency across guidelines may help ensure acceptance and an understanding of standards, but guidance developed elsewhere should not be applied uncritically: guidelines must address local context and be appropriate to the jurisdiction; should be as precise as possible in defining sensitive sites; use accepted, well-defined and standard vocabulary; explicitly indicate knowledge gaps; use indicators that have a scientific basis but can be applied operationally; and be developed jointly with potential users to ensure buy-in. Suitable site indicators that can be mapped (e.g. [200-202]), combined with spatial stand and harvesting data, can also be used to inventory the amount of environmentally sustainable biomass potentially available for the bioenergy and bioproducts sectors [203, 204]. Carbon management is a primary impetus for using forest biomass as energy feedstock and should be addressed in guidelines. Guidelines should be updated in a timely manner through an active 
adaptive management process [103, 104] as knowledge and practices improve (i.e. compliance, effectiveness and validation monitoring) to ensure that biomass harvesting practices are sustainable and can help mitigate climate change.

Forest biomass harvesting guidelines development takes place at the nexus where scientific knowledge, forest management, operational experience, policy, and societal expectations meet. Scientific knowledge of ecosystem processes underpins guideline development, but stakeholder objectives determine how this knowledge is applied. Effective guideline development and application can help ensure biomass harvesting is environmentally sustainable and can contribute to fossil fuel displacement. We trust that this broad review helps to bridge the gap between forest management, forest science and bioenergy policy; is useful to all stakeholders involved in guideline development; and stimulates scientific research to better identify indicators, thresholds and actions for forest biomass harvesting that are suitable at the spatial and temporal scales required for sustainable forest management.

\begin{abstract}
Abbreviations
AMP: Acceptable management practices; ANSI: American National Standards Institute; AWC: Available water (or water-holding) capacity; BMP: Best management practices; C: Carbon; CEC: Cation exchange capacity; CWD: Coarse woody debris; dbh: Diameter at breast height; DWM: Downed woody material; eNGO: Environmental non-governmental organization; EU: European Union; FiT: Feed-in tariff; FSC: Forest Stewardship Council; FWD: Fine woody debris; FWM: Fine woody material; GHG: Greenhouse gas; GIS: Geographic Information System; ISO: International Organization for Standardization; LCA: Life cycle analysis; NGO: Non-governmental organization; NMSD: Non-state market-driven; NRCS: Natural Resources Conservation Service; OECD: Organisation for Economic Cooperation and Development; PEFC: Programme for the Endorsement of Forest Certification; PJ: Picojoule, or $1 \times 10^{12} \mathrm{~J}$ of energy; SFI: Sustainable Forestry Initiative; SFM: Sustainable forest management; SOM: Soil organic matter; SRIC: Short rotation intensive culture; UK: United Kingdom of Great Britain and Northern Ireland; US or USA: Unites States of America.
\end{abstract}

\section{Supplementary Information}

The online version contains supplementary material available at https://doi. org/10.1186/s13705-021-00281-w.

Additional file 1. Additional tables derived from guidelines.

Additional file 2. Additional tables derived from reviews of guidelines.

\section{Acknowledgements}

The authors thank the following (in alphabetical order, with affiliations at the time) for their assistance in locating and/or clarifying the content of documents used in this review, and in preparation of Fig. 1: John Greis (USDA Forest Service, Southern Region, Tallahassee, Florida), Sarah Herrick (Division of Forestry, Dept. of Natural Resources, Wisconsin), Shawn Morehouse (Forest Management Branch, Dept. of Natural Resources, New Brunswick), Catherine Oldham (Forest Research Information Service, Forest Research, UK), Robert Slesak (Minnesota Forest Resources Council), Alice Solyma (Pacific Forestry Centre library, Canadian Forest Service, Natural Resources Canada; now deceased), Gurp Thandi and Kangakola Omendja (Pacific Forestry Centre, Canadian Forest
Service, Natural Resources Canada) for creating Fig. 1, and Bill Wilkinson (US Senior Forester, Forest Stewardship Council).

\section{Authors' contributions}

All authors contributed to identifying guidelines, extracting key information from them (and translating from original languages when necessary), entering information, and the development, revision and finalisation of the manuscript. All authors read and approved the final manuscript. In more detail: the project was conceived and begun by BT and IS, and then expanded in geographical scope through an OECD-funded workshop organised and led by H-S.H and EV (Forest bioenergy and soil sustainability). BT and IS initiated a search for guidelines documents and continued this over the lifetime of the project. With oversight by BT and IS, construction of Additional file 1: Table ST-1 was initiated by PR and KH, who completed much of the data entry for Englishlanguage guidelines (largely North American), supplemented by BT; European and East Asian guidelines were then largely entered by other co-authors, and translated into English when necessary, sometimes by BT. KB refined the content and structure of Additional file 1:Table ST-1 further and added BMPs that were linked to guidelines. BT added the most recent guidelines before ms. submission. PR initiated and KB re-worked and completed summary tables in Additional file 1; BT completed Additional file 1 for publication, and compiled past reviews and used these to construct Additional file 2. BT, IS, $\mathrm{H}-\mathrm{S}$.H and EV developed the ms. outline, KB wrote a first draft in collaboration with BT, which was developed further with input by IS, $\mathrm{H}-\mathrm{S}$.H and $\mathrm{EV}$ before input from remaining co-authors was incorporated through two further revisions. Development of the review was aided through discussion of preliminary results presented by BT at workshops and conferences, including the initial one organized by $\mathrm{H}-\mathrm{S}$.H and EV (Forest bioenergy and soil sustainability) and later ones organized by VB (Guidelines for Sustainable Forest Biomass Production) and IS (Governing sustainability of bioenergy, biomaterial and bioproduct supply chains from forest and agricultural landscapes), and in which some authors also participated (see also Funding below).

\section{Funding}

Financial support from the OECD Co-operative Research Programme on Biological Resource Management for Sustainable Agricultural Systems to $\mathrm{H}-\mathrm{S} \mathrm{H}$ and EV made organisation of a workshop on Forest bioenergy and soil sustainability possible at the Eurosoil Congress in Bari, Italy, 2-6 July 2012. This workshop (see proceedings) led to the collection and review of guidelines from different jurisdictions around the world. Authors were supported by their respective institutions, and $B T$ received funding from the OECD via $\mathrm{H}-\mathrm{S}$ $\mathrm{H}$ and $\mathrm{EV}$, with later funding to $\mathrm{BT}$ through the Sustainable Forest Management program of the Canadian Forest Service of Natural Resources Canada. Various authors participated in international projects, conferences, and workshops through funding from organizers of these, where they presented results as they developed to all participants, and took the opportunity to meet with some of the other authors to develop the guideline review further. In addition to the OECD-sponsored workshop on Forest bioenergy and soil sustainability in Bari, these events included Guidelines for Sustainable Forest Biomass Production - Challenges in view of an emerging bioeconomy, 11 Sept. 2017 in Vienna (see report at https://doi.org/10.1553/KIOESOP_009), organized by the Commission for Interdisciplinary Ecological Studies (KIOES) of the Austrian Academy of Sciences (OeAW); IUFRO's Forest Biomass Network Task Force (2014-19); and Governing sustainability of bioenergy, biomaterial and bioproduct supply chains from forest and agricultural landscapes, 17-19 April 2018 in Copenhagen, Denmark (see proceedings), supported by IEA Bioenergy Task 43, SNS-NKJ and CAR-ES and under whose auspices this review is published.

\section{Availability of data and materials}

The datasets supporting the conclusions of this article are included in the article as tables and figures, or supplementary tables in Additional files 1 and 2.

\section{Ethics approval and consent to participate}

Not applicable.

\section{Consent for publication}

Not applicable.

\section{Competing interests}

The authors declare that they have no competing interests. 


\section{Author details}

${ }^{1}$ Canadian Forest Service, Pacific Forestry Centre, Natural Resources Canada, 506 West Burnside Rd, Victoria, BC V8Z 1M5, Canada. ${ }^{2}$ Present Address: Retired and now Visiting Scientist at Pacific Forestry Centre, Victoria, BC V8Z 1M5, Canada. ${ }^{3}$ Present Address: K.R. Brown and Associates, 4043 Zinnia Rd, Victoria, BC V8Z 4W2, Canada. ${ }^{4}$ Department of Forest Sciences, University of Helsinki, PO Box 27, 00014 Helsinki, Finland. ${ }^{5}$ Forest Research, Alice Holt Lodge, Farnham GU10 4LH, Surrey, UK. ${ }^{6}$ Department of Geosciences and Natural Resource Management, University of Copenhagen, Rolighedsvej 23, 1958 Frederiksberg C, Copenhagen, Denmark. ${ }^{7}$ Forest Stewards Guild, 2019 Galisteo Street, Suite N7, Santa Fe, NM 87505, USA. ${ }^{8}$ Norwegian Institute of Bioeconomy Research, P.O. Box 115, N-1431 Ås Viken, Norway. ${ }^{9}$ Swiss Federal Institute for Forest, Snow and Landscape Research, 8903 Birmensdorf, Switzerland. ${ }^{10}$ Austrian Academy of Sciences (ÖAW), Commission for Interdisciplinary Ecological Studies (KIOES), 1010 Vienna, Austria. ${ }^{11}$ Institute of Forestry, Lithuanian Research Centre for Agriculture and Forestry, Liepu 1, Girionys, LT-53101 Kaunas, Lithuania. ${ }^{12}$ Wageningen University and Research, Environmental Systems Analysis Group, PO Box 47, 6700AA Wageningen, The Netherlands. ${ }^{13}$ Department of Forest Soils, Forestry and Forest Products Research Institute, Tsukuba, Ibaraki 305-8687, Japan. ${ }^{14}$ Department of Natural Resources and Environmental Science, California Polytechnic State University, San Luis Obispo, CA, USA. ${ }^{15}$ Present Address: Stantec, 11-2042 Mills Road, Sidney, BC V8L 5X4, Canada.

Received: 1 September 2020 Accepted: 22 February 2021 Published online: 14 April 2021

\section{References}

1. Yeh S, Witcover J, Lade GE, Sperling D (2016) A review of low carbon fuel policies: Principles, program status and future directions. Energy Policy 97:220-234. https://doi.org/10.1016/j.enpol.2016.07.029

2. World Bioenergy Association (2019) Global Bioenergy Statistics 2019. World Bioenergy Association, Stockholm

3. World Bioenergy Association (2017) WBA Global Bioenergy Statistics 2017. World Bioenergy Association, Stockholm

4. Swedish Energy Agency (2017) Energy in Sweden Facts and Figures. http://www.energimyndigheten.se/en/facts-and-figures/publications/. Accessed 12 Apr 2020

5. Statistics Finland (2017) Official Statistics of Finland: Energy supply and consumption. http://www.stat.fi/til/ehk/2017/ehk_2017_2018-12-11_ tie_001_en.html. Accessed 12 Apr 2020

6. International Energy Agency (2017) Technology roadmap: delivering sustainable bioenergy. Int Energy Agency. https://www.ieabioener gy.com/wp-content/uploads/2017/11/Technology_Roadmap_Deliv ering_Sustainable_Bioenergy.pdf. Accessed 25 Feb 2021

7. Commission E (2016) Proposal for a directive of the European Parliament and of the Council on the promotion of the use of energy from renewable sources (recast). European Commission, Brussels

8. van Stralen J, Kraan C, Uslu A et al (2016) Deliverable 7.3 Integrated assessment of biomass supply chains and conversion routes under different scenarios. S2Biom Project Grant Agreement no 608622. https:// www.s2biom.eu/images/Publications/D7.3_S2Biom_Integrated_Asses sment_Final2.pdf. Accessed 25 Feb 2021

9. IRENA (2019) Bioenergy from boreal forests Swedish approach to sustainable wood use. International Renewable Energy Agency, Abu Dhabi

10. Nicholls DL, Monserud RA, Dykstra DP (2008) Biomass utilization for bioenergy in the western United States. For Prod J 58:6-16. https://doi. org/10.1016/B978-0-444-63475-7.00011-X

11. Kirkland J (2015) Bioenergy from forests: the power potential of woody biomass. U.S Department of Agriculture Forest Service Pacific Northwest Research Station, Portland

12. Arasto A, Chiaramonti D, Kiviluoma J et al (2017) Bioenergy 's role in balancing the electricity grid and providing storage options-an EU perspective. IEA Bioenergy Task 41P6: 2017: 01. https://www.ieabioener gy.com/wp-content/uploads/2017/02/IEA-Bioenergy-Bioenergy-inbalancing-the-grid_master_FINAL-Revised-16.02.17.pdf. Accessed 25 Feb 2021
13. Brack D (2017) The impacts of the demand for woody biomass for power and heat on climate and forests. Chatham House Rep. https:// doi.org/10.1016/B978-034071920-6/50011-X

14. Evans AM, Finkral AJ (2009) From renewable energy to fire risk reduction: A synthesis of biomass harvesting and utilization case studies in US forests. GCB Bioenergy 1:211-219. https://doi.org/10.1111/j.17571707.2009.01013.x

15. Becker DR, Larson D, Lowell EC (2009) Financial considerations of policy options to enhance biomass utilization for reducing wildfire hazards. For Policy Econ 11:628-635. https://doi.org/10.1016/j.forpol.2009.08.007

16. Abbas D, Current D, Ryans $M$ et al (2011) Harvesting forest biomass for energy-An alternative to conventional fuel treatments: Trials in the Superior National Forest, USA. Biomass Bioenerg 35:4557-4564. https:// doi.org/10.1016/j.biombioe.2011.06.030

17. Hurteau M, North M (2009) Fuel treatment effects on tree-based forest carbon storage and emissions under modeled wildfire scenarios. Front Ecol Environ 7:409-414. https://doi.org/10.1890/080049

18. Miner R, Buford M, Miner RA et al (2014) Forest carbon accounting considerations in US bioenergy policy. J For 112:591-606. https://doi. org/10.5849/jof.14-009

19. de Jong J, Akselsson C, Egnell G et al (2017) Realizing the energy potential of forest biomass in Sweden-How much is environmentally sustainable? For Ecol Manage 383:3-16. https://doi.org/10.1016/j. foreco.2016.06.028

20. Bridge SRJ, Cooligan D, Dye D et al (2005) Reviewing Canada 's national framework of criteria and indicators for sustainable forest management. For Chron 81:73-80

21. Fritsche UR, Iriarte L, de Jong J et al (2014) Extending the EU Renewable Energy Directive sustainability criteria to solid bioenergy from forests. Nat Resour Forum 38(2):129-140. https://doi.org/10.1111/1477-8947. 12042

22. Lattimore B, Smith CT, Titus BD et al (2009) Environmental factors in woodfuel production: Opportunities, risks, and criteria and indicators for sustainable practices. Biomass Bioenerg 33:1321-1342. https://doi. org/10.1016/j.biombioe.2009.06.005

23. Elliot WJ (2010) Effects of forest biomass use on watershed processes in the Western United States. West J Appl For 25:12-17

24. Bouget C, Lassauce A, Jonsell M (2012) Effects of fuelwood harvesting on biodiversity - a review focused on the situation in Europe 1 This article is one of a selection of papers from the International Symposium on Dynamics and Ecological Services of Deadwood in Forest Ecosystems. Can J For Res 42:1421-1432. https://doi.org/10.1139/×2012-078

25. Achat DL, Deleuze C, Landmann G et al (2015) Quantifying consequences of removing harvesting residues on forest soils and tree growth-a meta-analysis. For Ecol Manage 348:124-141. https://doi. org/10.1016/j.foreco.2015.03.042

26. Richter K (2016) A comparison of national sustainability schemes for solid biomass in the EU. Fern, Brussels

27. Tarr NM, Rubino MJ, Costanza JK et al (2016) Projected gains and losses of wildlife habitat from bioenergy-induced landscape change. GCB Bioenergy. https://doi.org/10.1111/gcbb.12383

28. University of Minnesota Extension (2019) Armillaria root rot. https:// extension.umn.edu/plant-diseases/armillaria-root-rot. Accessed $12 \mathrm{Apr}$ 2020

29. Government of New Brunswick (2008) Forest biomass harvesting policy number FMB 019 2008. https://www2.gnb.ca/content/dam/gnb/Depar tments/nr-rn/pdf/en/Publications/FMB0192008.pdf. Accessed 25 Feb 2021

30. Stupak I, Asikainen A, Jonsell M et al (2007) Sustainable utilisation of forest biomass for energy-Possibilities and problems: policy, legislation, certification, and recommendations and guidelines in the Nordic, Baltic, and other European countries. Biomass Bioenerg 31:666-684. https:// doi.org/10.1016/j.biombioe.2007.06.012

31. Evans A, Perschel R, Kittler B (2010) Revised assessment of biomass. Forest Stewards Guild, Santa Fe

32. Stupak I, Titus BD, Clarke N et al (2013) Approaches to soil sustainability in guidelines for forest biomass harvesting and production in forests and plantations. In: Helmisaari, H-S. \& Vanguelova E (ed) Workshop W6.1 Forest bioenergy and soil sustainability, EUROSOIL Congress, July 2012, Bari, Italy. OECD, pp 14-21 
33. Commonwealth of Massachusetts (2017) Department of Energy Resources Alternative Energy Portfolio Standard Guideline on Biomass, Biogas, and Biofuels for Eligible Renewable Thermal Generation Units. Commonwealth of Massachusetts, Massachusetts

34. Commission F (2017) The UK Forestry Standard, 4th edn. Forestry Commission, Edinburgh

35. Taylor B, Kremsater L, Ellis R (1997) Adaptive management of forests in British Columbia. British Columbia Ministry of Forests Forest Practices Branch, Victoria

36. Vermont Department of Forests Parks and Recreation (2015) Voluntary harvesting guidelines for landowners in Vermont. Vermont Department of Forests Parks and Recreation, Montpelier

37. Measham TG, Kelly GJ, Smith FP (2007) Best management practice for complex problems: a case study of defining BMP for dryland salinity. Geogr Res. https://doi.org/10.1111/j.1745-5871.2007.00459.x

38. Neary DG (2013) Best management practices for forest bioenergy programs. WIREs Energy Env. https://doi.org/10.1002/wene.77

39. Fielding D, Cubbage F, Peterson MN et al (2012) Opinions of forest managers, loggers, and forest landowners in North Carolina regarding biomass harvesting guidelines. Int J For Res. https://doi.org/10.1155/ 2012/256141

40. Levin R, Eriksson H (2010) Good-practice guidelines for whole-tree harvesting in Sweden: moving science into policy. For Chron 86:51-56

41. Björheden R (2017) Development of bioenergy from forest biomass-a case study of Sweden and Finland. Croat J For Eng 38:259-268

42. Gerow T (2011) Lessons learned on the revision of the North Carolina forestry BMP manual. https://www.ncforestservice.gov/water_quality/ pdf/LessonsLearnedNCBMPRevision.pdf. Accessed 25 Feb 2021

43. Routa J, Asikainen A, Björheden R et al (2013) Forest energy procurement: state of the art in Finland and Sweden. Adv Bioenergy Sustain Chall 2:273-283. https://doi.org/10.1002/9781118957844.ch17

44. Hornung A (2014) Transformation of biomass: theory to practice. John Wiley and Sons, Chichester

45. Tuomasjukka D, Martire S, Lindner M et al (2018) Sustainability impacts of increased forest biomass feedstock supply — a comparative assessment of technological solutions. Int J For Eng 29:99-116. https://doi. org/10.1080/14942119.2018.1459372

46. Thiffault E, Béchard A, Paré D, Allen D (2014) Recovery rate of harvest residues for bioenergy in boreal and temperate forests: a review. WIREs Energy Env. https://doi.org/10.1002/9781118957844.ch19

47. Caputo J (2009) Sustainable forest biomass: promoting renewable energy and forest stewardship. Environ Energy Study Inst Policy Pap. https://www.eesi.org/files/eesi_sustforbio_final_070609.pdf. Accessed 25 Feb 2021

48. Vance ED, Aust WM, Strahm BD et al (2014) Biomass harvesting and soil productivity: is the science meeting our policy needs? Soil Sci Soc Am J 78:S95. https://doi.org/10.2136/sssaj2013.08.0323nafsc

49. Hannam KD, Deschamps C, Kwiaton M et al (2016) Regulations and guidelines for use of wood ash as soil amendment in Canadian forests. Natural Resources Canada Canadian Forest Service Information Rep. GLC-X-17. https://cfs.nrcan.gc.ca/publications?id=37781. Accessed 25 Feb 2021

50. Stupak I, Asikainen A, Roser D, Pasanen K (2008) Review of recommendations for forest energy harvesting and wood ash recycling. In: Roser D, Asikainen A, Raulund-Rasmussen K, Stupak I (eds) Sustainable use of forest biomass for energy: a synthesis with focus on the Baltic and Nordic Region. Managing forest ecosystems, vol 12. Springer, Dordrecht, pp 155-196

51. Berch SM, Curran M, Dymond C et al (2012) Criteria and guidance considerations for sustainable tree stump harvesting in British Columbia. Scand J For Res 27:709-723. https://doi.org/10.1080/02827581.2012. 725768

52. Kimura K (2017) Feed-in Tariffs in Japan: five years of achievements and future challenges. Renewable Energy Institute, Tokyo

53. Renard KG, Foster GR, Weesies GA et al (1997) Predicting soil erosion by water: a guide to conservation planning with the Revised Universal Soil Loss Equation (RUSLE). United States Department of Agriculture. Agricultural Research Service Agriculture Handbook 703. https://www. ars.usda.gov/ARSUserFiles/64080530/RUSLE/AH_703.pdf. Accessed 25 Feb 2021
54. Kittler BA, Beauvais CM (2010) The potential for sustainable wood-based bioenergy in Maryland. Pinchot Institute for Conservation, Washington

55. Pyatt DG (1982) Soil classification. Forestry Commission, Edinburgh

56. Nisbet T, Dutch J, Moffat A (1997) Whole -Tree Harvesting. Forestry Commission, Edinburgh

57. Wisconsin Department of Natural Resources (2018) Chapter 7-Forest soil productivity. In: Wisconsin forest management guidelines. Madison, WI, pp. 7-1-7-13. https://dnr.wisconsin.gov/topic/forestmanagement/ guidelines. Accessed 25 Feb 2021

58. Soil Science Division Staff (2017) Soil survey manual. United States Department of Agriculture Handbook 18. https://www.nrcs.usda.gov/ wps/portal/nrcs/detailfull/soils/ref/?cid=nrcs142p2_054262. Accessed 25 Feb 2021

59. Cajander AK (1949) Forest types and their significance. Acta For Fenn 56:1-71. https://doi.org/10.14214/aff.7396

60. Briggs RD (1994) Site classification field guide. Maine Agricultural and Forest Experiment Station. Misc Publ 724, CFRU Tech Note 6. ISSN 1070-1508

61. U.S. Department of Agriculture Natural Resources Conservation Service (2017) National soil survey handbook, title 430-VI. https://www.nrcs. usda.gov/wps/portal/nrcs/detail/soils/ref/?cid=nrcs142p2_054242. Accessed 25 Feb 2021

62. Commonwealth of Massachusetts Executive Office of Energy and Environmental Affairs (2012) Massachusetts renewable portfolio energy standard 225 CMR 14.00 Forest derived eligible biomass woody fuel guidelines. https://www.mass.gov/service-details/statutes-regulationsand-guidelines. Accessed 25 Feb 2021

63. Catanzaro P, Fish J, Kittredge D (2013) Best management practices manual. Massachusetts Dept of Conservation and Recreation. https:// www.mass.gov/doc/massachusetts-forestry-best-management-pract ices-manual-0/download. Accessed 25 Feb 2021

64. Prescott CE, Maynard DG, Laiho R (2000) Humus in northern forests: Friend or foe? For Ecol Manage 133:23-36. https://doi.org/10.1016/ S0378-1127(99)00295-9

65. Harrison RB, Maguire DA, Page-Dumroese D (2011) Maintaining adequate nutrient supply-Principles. decision-support tools, and best management practices. In: Angima SD, Terry TA (eds) Best management practices for managing soil productivity in the Douglas-fir region. Oregon State University Extension Service, Corvallis, pp 33-42

66. Helmisaari HS, Hanssen $\mathrm{KH}$, Jacobson S et al (2011) Logging residue removal after thinning in Nordic boreal forests: Long-term impact on tree growth. For Ecol Manage 261:1919-1927. https://doi.org/10.1016/j. foreco.2011.02.015

67. Commission F (2011) The UK Forestry Standard, 3rd edn. Forestry Commission, Edinburgh

68. U.K. Environment Agency (2014) Using waste: waste exemptions. U4 Burning of waste as a fuel in a small appliance, and U14 Incorporating ash into soil. https://www.gov.uk/government/collections/wasteexemptions-using-waste. Accessed 13 Apr 2020

69. U.K. Environment Agency (2014) Waste exemption: U11 spreading waste to benefit non-agricultural land. https://www.gov.uk/guidance/ waste-exemption-u11-spreading-waste-to-benefit-non-agriculturalland. Accessed 13 Apr 2020

70. Swedish Forest Agency (2008) Recommendations for extraction and ash recycling. English translation of Rekommendationer vid uttag av avverkningsrester och askaterforing. Swedish Forest Agency Meddelande (Letter) 2:2008. ISSN 1100-0295. https://shopcdn.textalk.se/shop/ 9098/art78/4645978-f6de2e-guidelines.pdf. Accessed 25 Feb 2021

71. Holzner H, Steiermark LK, Obernberger I (2011) Land- und Forstwirtschaftlich Fachbeirat fur Bodenfruchtbarkeit und Bodenschutz. Vienna

72. South Carolina Department of Health and Environmental control (1996) SWM: land application of solid waste regulation 61-107.15. https:// scdhec.gov/sites/default/files/docs/Agency/docs/lwm-regs/61-107_15. pdf. Accessed 25 Feb 2021

73. Commission F (2009a) Guidelines on site selection for brash removal. Forestry Commission, Edinburgh

74. Ranius T, Caruso A, Jonsell M et al (2014) Dead wood creation to compensate for habitat loss from intensive forestry. Biol Conserv 169:277-284. https://doi.org/10.1016/j.biocon.2013.11.029 
75. Evans AM (2012) Ecology of dead wood in the Southeast. Forest Stewards Guild, Santa Fe

76. Herrick S, Kovach J, Padley E, Wagner C (2008) Wisconsin's Forestland Woody Biomass Harvesting Guidelines: Rationale for the Guidelines. Madison, Wl

77. Rose CL, Marcot BG, Mellen TK et al (2001) Decaying wood in Pacific Northwest forests: Concepts and tools for habitat management. In: Johnson DH, O'Neil TA (eds) Wildlife-habitat relationships in Oregon and Washington. Oregon State University Press, Corvallis, pp 580-623

78. Repo A, Känkänen R, Tuovinen JP et al (2012) Forest bioenergy climate impact can be improved by allocating forest residue removal. GCB Bioenergy. https://doi.org/10.1111/j.1757-1707.2011.01124.x

79. Ranius T, Hämäläinen $\mathrm{A}$, Egnell $\mathrm{G}$ et al (2018) The effects of logging residue extraction for energy on ecosystem services and biodiversity: a synthesis. J Environ Manage 209:409-425. https://doi.org/10.1016/j. jenvman.2017.12.048

80. Ring E, Johansson J, Sandström C et al (2017) Mapping policies for surface water protection zones on forest land in the Nordic-Baltic region: large differences in prescriptiveness and zone width. Ambio 46:878-893. https://doi.org/10.1007/s13280-017-0924-8

81. Commission F (2009b) Stump Harvesting: Interim Guidance on Site Selection and Good Practice. Forestry Commission, Edinburgh

82. Collison J, Wilson C, Moffat A, Gallacher J (2015) Soil physical disturbance resulting from stump harvesting. Scottish For 69:20-27

83. Vanguelova El, Pitman R, Benham S et al (2017) Impact of Tree Stump Harvesting on Soil Carbon and Nutrients and Second Rotation Tree Growth in Mid-Wales, UK. Open J For 07:58-78. https://doi.org/10.4236/ ojf.2017.71005

84. Vanguelova E, Pitman R, Luiro J, Helmisaari HS (2010) Long term effects of whole tree harvesting on soil carbon and nutrient sustainability in the UK. Biogeochemistry 101:43-59. https://doi.org/10.1007/ s10533-010-9511-9

85. Biomass Energy Working Group (2012) Biomass Energy Development Working Group: Final report to the legislative council, State of Vermont. Montpelier VT. https://doi.org/10.13140/2.1.5110.6888

86. Gundersen V, Clarke N, Dramstad W, Fjellstad W (2016) Effects of bioenergy extraction on visual preferences in boreal forests: a review of surveys from Finland, Sweden and Norway. Scand J For Res 31:323-334. https://doi.org/10.1080/02827581.2015.1099725

87. Roach J, Berch S (2014) A compilation of forest biomass harvesting and related policy in Canada. Province of British Columbia Tech. Rep. 081, Victoria, BC. https://www.for.gov.bc.ca/hfd/pubs/docs/tr/TR081.pdf. Accessed 25 Feb 2021

88. National Association of State Foresters (2015) Protecting water quality through state forestry best management practices. National Association of State Foresters, Washington

89. Ontario Ministry of Natural Resources (OMNR) (2008) Forest Biofibre - allocation and use. Forest management forest resource disposition directive FOR 0302 01. https://www.ontario.ca/page/forest-biofibreallocation-and-use\#section-4. Accessed 25 February 2021

90. Puddister D, Dominy SWJ, Baker JA et al (2011) Opportunities and challenges for Ontario's forest bioeconomy. For Chron 87:468-475. https:// doi.org/10.5558/tfc2011-045

91. Simpson J (2015) Forest biomass energy policy in the maritime provinces: Accounting for science. East Coast Environmental Law, Halifax

92. Stewart W, Powers RF, Mcgown K et al (2011) Potential positive and negative environmental impacts of increased woody biomass use for California: Public Interest Energy Research (PIER) Program Final Project Report to the California Energy Commission. https://ucanr.edu/sites/ forestry/files/161616.pdf. Accessed 25 Feb 2021

93. Evans AM (2016) Potential ecological consequences of forest biomass harvesting in California. J Sustain For 35:1-15. https://doi.org/10.1080/ 10549811.2015.1104254

94. Oregon Department of Forestry (2008) Report: environmental effects of forest biomass removal. Report submitted by the Office of the State Forester, Oregon Department of Forestry to the Oregon Legislature, Dec 1, 2008

95. Washington State Department of Natural Resources (2011) Update to the 2012 Washington state legislature on DNR's forest biomass initiative: Bioaviation fuel production from residual woody biomass. Washington State Department of Natural Resources, December 1, 2011. https://file.dnr.wa.gov/publications/em_2011leg_rept_biom_upda.pdf. Accessed 25 Feb 2021

96. Washington Department of Natural Resources Forest Practices Biomass Work-Group (2012) Final Report to the Forest Practices Board. https:// file.dnr.wa.gov/publications/em_final_report_2012_fp_biomass_work_ group.pdf. Accessed 25 Feb 2021

97. Commission E (2014) State of play on the sustainability of solid and gaseous biomass used for electricity, heating and cooling in the EU. European Commission, Brussels

98. Abt KL, Abt RC, Galik C (2012) Effect of bioenergy demands and supply response on markets, carbon, and land use. For Sci 58:523-539. https:// doi.org/10.5849/forsci.11-055

99. Galik CS, Abt RC (2016) Sustainability guidelines and forest market response: an assessment of European Union pellet demand in the southeastern United States. GCB Bioenergy 8:658-669. https://doi.org/ $10.1111 /$ gcbb. 12273

100. Koistinen A, Luiro J-P, Vanhatalo K (toim.) (2016) Metsänhoidon suositukset energiapuun korjuuseen, työopas. Tapion julkaisuja. ISBN 978-952-5632-35-4, Julkaistu verkossa, 2.6.2016. https://tapio.fi/wpcontent/uploads/2015/06/MHS-Energiapuun-korjuun-suositukset_ verkkojulkaisu2.pdf. Accessed 25 Feb 2021

101. Reader R (2006) The expectations that affect the management of public forest and range lands in British Columbia: Looking outside the legislation. Discussion Paper prepared for the Ministry of Forests and Range and the Ministry of Environment, Victoria, BC. https://www2.gov.bc.ca/ assets/gov/environment/natural-resource-policy-legislation/legislationregulation/frpa-pac/looking_outside_the_legislation.pdf. Accessed 25 Feb 2021

102. Vance ED, Prisley SP, Schilling EB et al (2018) Environmental implications of harvesting lower-value biomass in forests. For Ecol Manage 407:47-56. https://doi.org/10.1016/j.foreco.2017.10.023

103. Williams BK (2011) Adaptive management of natural resources-framework and issues. J Environ Manage 92:1346-1353. https://doi.org/10. 1016/j.jenvman.2010.10.041

104. Curran MP, Maynard DG, Heninger RL et al (2005) An adaptive management process for forest soil conservation. For Chron 81:717-722. https://doi.org/10.5558/tfc81717-5

105. Briedis JI, Wilson JS, Benjamin JG, Wagner RG (2011) Biomass retention following whole-tree, energy wood harvests in central Maine: Adherence to five state guidelines. Biomass Bioenerg 35:3552-3560. https:// doi.org/10.1016/j.biombioe.2011.05.018

106. Fritts SR, Moorman CE, Hazel DW, Jackson BD (2014) Biomass harvesting guidelines affect downed woody debris retention. Biomass Bioenerg 70:382-391. https://doi.org/10.1016/j.biombioe.2014.08.010

107. Egnell $G$ (2017) A review of Nordic trials studying effects of biomass harvest intensity on subsequent forest production. For Ecol Manage 383:27-36. https://doi.org/10.1016/j.foreco.2016.09.019

108. Ponder F, Fleming RL, Berch S et al (2012) Effects of organic matter removal, soil compaction and vegetation control on 10th year biomass and foliar nutrition: LTSP continent-wide comparisons. For Ecol Manage 278:35-54. https://doi.org/10.1016/j.foreco.2012.04.014

109. Root HT, Betts MG (2016) Managing moist temperate forests for bioenergy and biodiversity. J For 114:66-74

110. Lindenmayer DB, Franklin JF, Fischer J (2006) General management principles and a checklist of strategies to guide forest biodiversity conservation. Biol Conserv 131:433-445. https://doi.org/10.1016/j.biocon. 2006.02.019

111. Sullivan TP, Sullivan DS, Sullivanrah JH (2017) Mammalian responses to windrows of woody debris on clearcuts: abundance and diversity of forest-floor small mammals and presence of small mustelids. For Ecol Manage 399:143-154. https://doi.org/10.1016/j.foreco.2017.05.028

112. Larson AJ, Belote RT, Williamson MA, Aplet GH (2013) Making monitoring count: Project design for active adaptive management. J For 111:348-356. https://doi.org/10.5849/jof.13-021

113. MacDonald GB, Rice JA (2004) An active adaptive management case study in Ontario boreal mixedwood stands. For Chron 80:391-400. https://doi.org/10.5558/tfc80391-3

114. Morris DM, Fleming RL, Hazlett PW (2020) Ontario, Canada's LTSP experience: forging lasting research partnerships and the adaptive management cycle in action. J For 118:337-351. https://doi.org/10.1093/jofore/ fvaa002 
115. Stape JL, Binkley D, Jacob WS, Takahashi EN (2006) A twin-plot approach to determine nutrient limitation and potential productivity in Eucalyptus plantations at landscape scales in Brazil. For Ecol Manage 223:358-362. https://doi.org/10.1016/j.foreco.2005.11.015

116. da Silva RML, Hakamada RE, Bazani JH et al (2016) Fertilization response, light use, and growth efficiency in Eucalyptus plantations across soil and climate gradients in Brazil. Forests 7:2-13. https://doi.org/10.3390/ f7060117

117. Thiffault E, Paré D, Dagnault S, Morissette J (2011) Establishing permanent plots for monitoring the environmental effects of forest biomass harvesting: guidelines. Natural Resources Canada Canadian Forest Service, Laurentian Forestry Centre, Quebec

118. Natureserve: Connecting Science with Conservation Natureserve. http://www.natureserve.org. Accessed 12 Apr 2020

119. Evans AM, Kelty MJ (2010) Ecology of dead wood in the Northeast. Forest Stewards Guild, Santa Fe

120. Cleary MR, Arhipova N, Morrison DJ et al (2013) Stump removal to control root disease in Canada and Scandinavia: a synthesis of results from long-term trials. For Ecol Manage 290:5-14. https://doi.org/10.1016/j. foreco.2012.05.040

121. Kardell L (2010) Skogsenergiförsöken 1977-2008. Institutionen for Skoglig Landskapsvard Swedish University of Agricultural Sciences Department of Environmental Forestry, Uppsala

122. Kangas HL, Lyytimäki J, Saarela SR, Primmer E (2018) Burning roots: stakeholder arguments and media representations on the sustainability of tree stump extraction in Finland. Biomass Bioenerg 118:65-73. https://doi.org/10.1016/j.biombioe.2018.08.006

123. Royal Swedish Academy of Agriculture and Forestry (2015) Forests and forestry in Sweden. Royal Swedish Academy of Agriculture and Forestry, Stockholm

124. Persson T (2012) Tree stumps for bioenergy — harvesting techniques and environmental consequences. Scand J For Res 25:705-708. https:// doi.org/10.1080/02827581.2012.726520

125. BC Ministry of Forests, Mines and Lands (2010) The State of British Columbia's Forests, Third Edition. BC Ministry of Forests, Mines and Lands, Victoria, BC. https://www2.gov.bc.ca/assets/gov/environment/ research-monitoring-and-reporting/reporting/envreportbc/archivedreports/sof_2010.pdf. Accessed 25 Feb 2021

126. Berch SM, Bulmer C, Curran M et al (2012) Provincial government standards, criteria, and indicators for sustainable harvest of forest biomass in British Columbia: soil and biodiversity. Int J For Eng 23:33-37. https:// doi.org/10.1080/14942119.2012.10739958

127. Vasaitis R, Stenlid J, Thomsen IM et al (2008) Stump removal to control root rot in forest stands. A literature study. Silva Fenn 42:457-483. https://doi.org/10.14214/sf.249

128. Walmsley JD, Godbold DL (2010) Stump harvesting for bioenergy-a review of the environmental impacts. Forestry 83:17-38. https://doi. org/10.1093/forestry/cpp028

129. Persson $\mathrm{T}$ (2016) Stump harvesting —impact on climate and environment. For Ecol Manage 371:1-4. https://doi.org/10.1016/j.foreco.2016. 04.046

130. Persson T (2017) Stump harvesting for bioenergy-methods and environmental effects. Scand J For Res 32:201-203. https://doi.org/10.1080/ 02827581.2017 .1289714

131. Persson T, Egnell G (2018) Stump harvesting for bioenergy: a review of climatic and environmental impacts in northern Europe and America. Wiley Interdiscip Rev Energy Environ 7:1-26. https://doi.org/10.1002/ wene.307

132. Hannam K (2012) The use of stumps for biomass in British Columbia-a problem analysis. Province of British Columbia, Victoria

133. BC Ministry of Forests, Lands, and Natural Resource Operations (2015) Stump and large root removal to control root disease. BC Ministry of Forests, Lands, and Natural Resource Operations, Resource Practices Branch, September 2015. https://www.for.gov.bc.ca/ftp/HFP/external/ !publish/Forest_Health/Root\%20Diseases/Stump\%20and\%20large\% 20root\%20removal\%20to\%20control\%20root\%20disease_2.0_hk_ Sep\%2030.pdf. Accessed 25 Feb 2021

134. Berg S, Bergström D, Athanassiadis D, Nordfjell T (2012) Torque required to twist and cut loose Scots pine stumps. Scand J For Res 27:724-733. https://doi.org/10.1080/02827581.2012.721002
135. Kaarakka L, Vaittinen J, Marjanen M et al (2018) Stump harvesting in Picea abies stands: soil surface disturbance and biomass distribution of the harvested stumps and roots. For Ecol Manage 425:27-34. https:// doi.org/10.1016/j.foreco.2018.05.032

136. USDA Natural Resource Conservation Service Soil Survey. https://www. nrcs.usda.gov/wps/portal/nrcs/main/soils/survey/. Accessed 25 Feb 2021

137. Bronson D, Edge G, Hardin C et al (2014) Wisconsin's forestland woody biomass harvesting guidelines-Field manual for loggers, landowners, and land managers. Wisconsin Department of Natural Resources Division of Forestry Wisconsin Council on Forestry PUB-FR-435-2014, Madison

138. Walker T, Cardellichio P, Colnes A et al (2010) Biomass sustainability and carbon policy study. Manomet Center for Conservation Sciences, Manomet, MA. https://grist.org/wp-content/uploads/2011/07/ manomet_biomass_report_full_lorez.pdf. Accessed 25 Feb 2021

139. Schulze ED, Körner $\bar{C}$, Law BE et al (2012) Large-scale bioenergy from additional harvest of forest biomass is neither sustainable nor greenhouse gas neutral. GCB Bioenergy 4:611-616. https://doi.org/10.1111/j. 1757-1707.2012.01169.x

140. Lamers P, Junginger M (2013) The "debt" is in the detail: a synthesis of recent temporal forest carbon analyses on woody biomass for energy. Biofuels Bioprod Biorefining. https://doi.org/10.1002/bbb.1407

141. Clarke N, Gundersen P, Jönsson-Belyazid U et al (2015) Influence of different tree-harvesting intensities on forest soil carbon stocks in boreal and northern temperate forest ecosystems. For Ecol Manage 351:9-19. https://doi.org/10.1016/j.foreco.2015.04.034

142. Repo A, Ahtikoski A, Liski J (2015) Cost of turning forest residue bioenergy to carbon neutral. For Policy Econ 57:12-21. https://doi.org/10. 1016/j.forpol.2015.04.005

143. Booth MS (2018) Not carbon neutral: Assessing the net emissions impact of residues burned for bioenergy. Environ Res Lett 13:035001. https://doi.org/10.1088/1748-9326/aaac88

144. Malmsheimer RW, Bowyer JL, Fried JS et al (2011) Managing forests because carbon matters: Integrating energy, products, and land management policy. J For 109:S7-S50. https://doi.org/10.1093/jof/109.s1.S7

145. Institute for Energy and the Environment (2015) Woody biomass: the path toward a sustainable use of Vermont's forests. Institute for Energy and the Environment, Vermont Law School, South Royalton, Vermont, USA. https://www.vermontlaw.edu/sites/default/files/Assets/iee/IEE_ PSD_FinalReport_WoodyBiomass_2015.pdf. Accessed 25 Feb 2021

146. Cowie AL, Smith P, Johnson D (2006) Does soil carbon loss in biomass production systems negate the greenhouse benefits of bioenergy? Mitig Adapt Strateg Glob Chang 11:979-1002. https://doi.org/10.1007/ s11027-006-9030-0

147. Creutzig F, Ravindranath NH, Berndes G et al (2015) Bioenergy and climate change mitigation: an assessment. GCB Bioenergy 7:916-944. https://doi.org/10.1111/gcbb.12205

148. Forest Guild Southeast Biomass Working Group (2012) Forest biomass retention and harvesting guidelines for the Southeast. Forest Stewards Guild, Santa Fe

149. Lippke B, Oneil E, Harrison R et al (2011) Life cycle impacts of forest management and wood utilization on carbon mitigation: knowns and unknowns. Carbon Manag 2:303-333. https://doi.org/10.4155/cmt.11. 24

150. CORRIM (2013) The role of forests, management, and forest products on carbon mitigation. CORRIM, Seattle

151. Olsson O, Bruce L, Hektor B et al (2016) Cascading of woody biomass: definitions, policies and effects on international trade. IEA Bioenergy Task 40 Working Paper. https://task40.ieabioenergy.com/wp-content/ uploads/sites/6/2013/09/t40-cascading-2016.pdf. Accessed 25 Feb 2021

152. IPCC (2019) Summary for policymakers. In: Masson-Delmotte V, Zhai P, Pörtner H-O et al (eds) Climate Change and Land An IPCC Special Report on climate change, desertification, land degradation, sustainable land management, food security, and greenhouse gas fluxes in terrestrial ecosystems. Intergovernmental Panel on Climate Change, Geneva

153. Johnson DW, Curtis PS (2001) Effects of forest management on soil C and N storage: meta analysis. For Ecol Manage 140:227-238 
154. Achat DL, Fortin M, Landmann $\mathrm{G}$ et al (2015) Forest soil carbon is threatened by intensive biomass harvesting. Sci Rep 5:1-10. https://doi.org/ 10.1038/srep15991

155. Nave LE, Vance ED, Swanston CW, Curtis PS (2010) Harvest impacts on soil carbon storage in temperate forests. For Ecol Manage 259:857-866. https://doi.org/10.1016/j.foreco.2009.12.009

156. James J, Harrison R (2016) The effect of harvest on forest soil carbon: a meta-analysis. Forests. https://doi.org/10.3390/f7120308

157. Mayer M, Prescott CE, Abaker WEA et al (2020) Influence of forest management activities on soil organic carbon stocks: a knowledge synthesis. For Ecol Manage 466:1 18127. https://doi.org/10.1016/j.foreco. 2020.118127

158. Clarke N, Kiær LP, Janne Kjønaas O et al (2021) Effects of intensive biomass harvesting on forest soils in the Nordic countries and the UK: A meta-analysis. For Ecol Manage. 482:118877. https://doi.org/10.1016/j. foreco.2020.118877

159. EU (2018) Directive (EU) 2018/2001 of the European Parliament and of the Council on the promotion of the use of energy from renewable sources. Off J Eur Union 2018:82-209

160. Bishop ID (2019) Evidence synthesis in landscape aesthetics: an honourable endeavour yet insufficient applicable knowledge. Socio-Ecological Pract Res 1:93-108. https://doi.org/10.1007/s42532-019-00011-9

161. Rosenberger RS, Smith EL (1997) Nonmarket economic impacts of forest insect pests: a literature review. USDA Forest Service, Pacific Southwest Research Station, Gen. Tech. Rep. PSW-GTR-164. https:// www.fs.fed.us/psw/publications/documents/psw_gtr164/psw_gtr164. pdf. Accessed 25 Feb 2021

162. Rosenberger RS, Smith EL (1998) Assessing forest scenic beauty impacts of insects and management. FHTET 98-08. USDA Forest Service Forest Health Enterprose Technology Team, Fort Collins, CO.

163. Hastik R, Basso S, Geitner C et al (2015) Renewable energies and ecosystem service impacts. Renew Sustain Energy Rev 48:608-623. https:// doi.org/10.1016/j.rser.2015.04.004

164. Gundersen VS, Frivold LH (2008) Public preferences for forest structures: A review of quantitative surveys from Finland, Norway and Sweden. Urban For Urban Green 7:241-258. https://doi.org/10.1016/j.ufug.2008. 05.001

165. Talbot B, Rahlf J, Astrup R (2018) An operational UAV-based approach for stand-level assessment of soil disturbance after forest harvesting. Scand J For Res 33:387-396. https://doi.org/10.1080/02827581.2017 1418421

166. Gundersen V, Stange EE, Kaltenborn BP, Vistad OI (2017) Public visual preferences for dead wood in natural boreal forests: The effects of added information. Landsc Urban Plan 158:12-24. https://doi.org/10. 1016/j.landurbplan.2016.09.020

167. Roberge JM, Laudon H, Björkman C et al (2016) Socio-ecological implications of modifying rotation lengths in forestry. Ambio 45:109-123. https://doi.org/10.1007/s13280-015-0747-4

168. Serenari C, Peterson MN, Moorman CE et al (2015) Application of choice experiments to determine stakeholder preferences for woody biomass harvesting guidelines. J Sustain For 34:343-357. https://doi.org/10. 1080/10549811.2015.1007511

169. Cristan R, Aust WM, Bolding MC et al (2016) Effectiveness of forestry best management practices in the United States: Literature review. For Ecol Manage 360:133-151. https://doi.org/10.1016/j.foreco.2015.10.025

170. Pannell DJ, Marshall GR, Barr N et al (2006) Understanding and promoting adoption of conservation practices by rural landholders. Aust J Exp Agric. https://doi.org/10.1071/EA05037

171. Bieling C (2004) Non-industrial private-forest owners: possibilities for increasing adoption of close-to-nature forest management. Eur J For Res 123:293-303. https://doi.org/10.1007/s10342-004-0042-6

172. Bergseng E, Vatn A (2009) Why protection of biodiversity creates conflict-Some evidence from the Nordic countries. J For Econ 15:147-165. https://doi.org/10.1016/.j.je.2008.04.002

173. De Meo I, Cantiani MG, Ferretti F, Paletto A (2011) Stakeholders' perception as support for forest landscape planning. Int J Ecol 2011:1-8. https://doi.org/10.1155/2011/685708

174. Urquhart J, Courtney P (2011) Seeing the owner behind the trees: a typology of small-scale private woodland owners in England. For Policy Econ. https://doi.org/10.1016/j.forpol.2011.05.010
175. Joshi O, Mehmood SR (2011) Factors affecting nonindustrial private forest landowners' willingness to supply woody biomass for bioenergy. Biomass Bioenerg 35:186-192. https://doi.org/10.1016/j.biombioe.2010. 08.016

176. Deuffic P, Lyser S (2012) Biodiversity or bioenergy: is deadwood conservation an environmental issue for French forest owners? 1 This article is one of a selection of papers from the International Symposium on Dynamics and Ecological Services of Deadwood in Forest Ecosystems. Can J For Res 42:1491-1502. https://doi.org/10.1139/×2012-073

177. Gruchy SR, Grebner DL, Munn IA et al (2012) An assessment of nonindustrial private forest landowner willingness to harvest woody biomass in support of bioenergy production in Mississippi: a contingent rating approach. For Policy Econ 15:140-145. https://doi.org/10.1016/j.forpol. 2011.09.007

178. Wolde B, Lal P, Alavalapati I et al (2016) Factors affecting forestland owners' allocation of non-forested land to pine plantation for bioenergy in Virginia. Biomass Bioenerg 85:69-75. https://doi.org/10.1016/j.biomb ioe.2015.12.007

179. Vanclay F (2004) Social principles for agricultural extension to assist in the promotion of natural resource management. Aust J Exp Agric 44:213-222. https://doi.org/10.1071/EA02139

180. U.S. Environmental Protection Agency (2005) National management measures to control nonpoint source pollution from forestry. U.S Environmental Protection Agency, Office of Water, Washington

181. Shepard JP (2006) Water quality protection in bioenergy production: the US system of forestry best management practices. Biomass Bioenerg 30:378-384. https://doi.org/10.1016/j.biombioe.2005.07.018

182. Ice GG, Schilling E, Vowell J (2010) Trends for forestry best management practices implementation. J For 108:267-273

183. Ice GG, Dent L, Robben J et al (2004) Programs assessing implementation and effectiveness of state forest practice rules and BMPs in the West. Water Air Soil Pollut Focus 4:143-169. https://doi.org/10.1023/B: WAFO.0000012821.68577.6b

184. Dwivedi P, Tumpach C, Cook C, Izlar B (2018) Effects of the sustainable forestry initiative fiber sourcing standard on the average implementation rate of forestry best management practices in Georgia, United States. For Policy Econ 97:51-58. https://doi.org/10.1016/j.forpol.2018. 08.016

185. Craig RK, Roberts AM (2015) When will governments regulate nonpoint source pollution? A comparative perspective. Bost Coll Environ Aff Law Rev 42:1-21

186. Barrett SM, Aust WM, Bolding MC et al (2016a) Implementation of forestry Best Management Practices on biomass and conventional harvesting operations in Virginia. Water (Switzerland) 8:9. https://doi. org/10.3390/w8030089

187. Barrett SM, Aust WM, Bolding MC et al (2016b) Estimated erosion, ground cover, and best management practices audit details for postharvest evaluations of biomass and conventional clearcut harvests. J For 114:9-16. https://doi.org/10.5849/jof.14-104

188. Arnstein SR (1969) A ladder of citizen participation. J Am Plan Assoc 35:216-224. https://doi.org/10.1080/01944366908977225

189. BBC (2019) UK Parliament declares climate emergency. UK Web News, 1 May 2019. https://www.bbc.com/news/uk-politics-48126677. Accessed 25 Feb 2021

190. Canadian Parliament (2019) Vote No. 1366. 42nd Parliament, 1st Session, Sitting No. 435 - Monday June 17, 2019. Sponsor: Ms. McKenna (Ottawa Centre). Motion: Government Business No. 29 (National climate emergency). https://www.ourcommons.ca/Members/en/votes/42/1/ 1366/. Accessed 25 Feb 2021

191. Carrington, D. (2019) Why the Guardian is changing the language it uses about the environment. Damian Carrington, Environment Editor, The Guardian web news, 17 May 2019. https://www.theguardian.com/ environment/2019/may/17/why-the-guardian-is-changing-the-langu age-it-uses-about-the-environment. Accessed 25 Feb 2021

192. U.S. Congress (2019) Rules of the One Hundred Sixteenth Congress. H. Res. 6 - 116th Congress (2019-2020). Sec. 104. Committees, Commissions, and House Offices. Resolution (f) (1) (A) There is hereby established a Select Committee on the Climate Crisis (2019)

193. Mainville N (2011) Fuelling a biomess: Why burning trees for energy will harm people, the climate and forests. Greenpeace Canada, Montreal 
194. Radics RI, Dasmohapatra S, Kelley SS (2016) Public perception of bioenergy in North Carolina and Tennessee. Energy Sustain Soc. https://doi. org/10.1186/s13705-016-0081-0

195. Bennett NJ, Satterfield T (2018) Environmental governance: a practical framework to guide design, evaluation, and analysis. Conserv Lett 11:1-13. https://doi.org/10.1111/conl.12600

196. Stupak I, Joudrey J, Smith CT et al (2016) A global survey of stakeholder views and experiences for systems needed to effectively and efficiently govern sustainability of bioenergy. Wiley Interdiscip Rev Energy Environ 5:89-118. https://doi.org/10.1002/wene.166

197. Stupak I, Lattimore B, Titus BD, Tattersall Smith C (2011) Criteria and indicators for sustainable forest fuel production and harvesting: a review of current standards for sustainable forest management. Biomass Bioenerg 35:3287-3308. https://doi.org/10.1016/J.BIOMBIOE.2010.11.032

198. Pelkmans L, Goovaerts L, Goh CS et al (2014) The role of sustainability requirements in international bioenergy markets. Springer, Netherlands

199. Thrän D, Schaubach K, Peetz D et al (2019) The dynamics of the global wood pellet markets and trade-key regions, developments and impact factors. Biofuels Bioprod Biorefining 13:267-280. https://doi.org/ $10.1002 / \mathrm{bbb} .1910$
200. Kimsey M, Page-Dumroese D, Coleman M (2011) Assessing bioenergy harvest risks: Geospatially explicit tools for maintaining soil productivity in western US forests. Forests 2:797-813. https://doi.org/10.3390/f2030 797

201. Thiffault E, Barrette J, Paré D et al (2014) Developing and validating indicators of site suitability for forest harvesting residue removal. Ecol Indic 43:1-18. https://doi.org/10.1016/j.ecolind.2014.02.005

202. Mateos E, Edeso JM, Ormaetxea L (2017) Soil erosion and forests biomass as energy resource in the basin of the Oka river in Biscay, Northern Spain. Forests 8:1-20. https://doi.org/10.3390/f8070258

203. Wiesenthal T, Mourelatou A, Petersen JE, Taylor P (2006) How much bioenergy can Europe produce without harming the environment? European Environment Agency, Copenhagen

204. Titus BD, Maynard DG, Dymond CC et al (2009) Wood energy: protect local ecosystems. Science 324:1389-1390

\section{Publisher's Note}

Springer Nature remains neutral with regard to jurisdictional claims in published maps and institutional affiliations.
Ready to submit your research? Choose BMC and benefit from:

- fast, convenient online submission

- thorough peer review by experienced researchers in your field

- rapid publication on acceptance

- support for research data, including large and complex data types

- gold Open Access which fosters wider collaboration and increased citations

- maximum visibility for your research: over 100M website views per year

At BMC, research is always in progress.

Learn more biomedcentral.com/submissions 